\title{
Localized Irradiation of Cell Membrane by Auger Electrons Is Cytotoxic Through Oxidative Stress-Mediated Nontargeted Effects
}

\author{
Salomé Paillas, ${ }^{1-5}$ Riad Ladjohounlou, ${ }^{1-4}$ Catherine Lozza, ${ }^{1-4}$ Alexandre Pichard, ${ }^{1-4}$ Vincent Boudousq, ${ }^{1-4}$ \\ Marta Jarlier, Samuel Sevestre, ${ }^{1-4}$ Marion Le Blay, ${ }^{1-4}$ Emmanuel Deshayes, ${ }^{1-4}$ Jane Sosabowski, $^{5}$ \\ Thierry Chardès, ${ }^{1-4}$ Isabelle Navarro-Teulon, ${ }^{1-4}$ Robert J. Mairs, ${ }^{6}$ and Jean-Pierre Pouget ${ }^{1-4}$
}

\begin{abstract}
Aims: We investigated whether radiation-induced nontargeted effects are involved in the cytotoxic effects of anticell surface monoclonal antibodies labeled with Auger electron emitters, such as iodine 125 (monoclonal antibodies labeled with ${ }^{125} \mathrm{I}\left[{ }^{125} \mathrm{I}\right.$-mAbs]). Results: We showed that the cytotoxicity of ${ }^{125} \mathrm{I}$-mAbs targeting the cell membrane of $\mathrm{p}^{2} 3^{++}$HCT116 colon cancer cells is mainly due to nontargeted effects. Targeted and nontargeted cytotoxicities were inhibited in vitro following lipid raft disruption with Methyl- $\beta$-cyclodextrin (MBCD) or filipin or use of radical oxygen species scavengers. ${ }^{125} \mathrm{I}-\mathrm{mAb}$ efficacy was associated with acid sphingomyelinase activation and modulated through activation of the AKT, extracellular signal-related kinase $1 / 2$ (ERK1/2), p38 kinase, c-Jun N-terminal kinase (JNK) signaling pathways, and also of phospholipase C- $\gamma$ (PLC- $\gamma$ ), proline-rich tyrosine kinase 2 (PYK-2), and paxillin, involved in $\mathrm{Ca}^{2+}$ fluxes. Moreover, the nontargeted response induced by directing $5-[(125) \mathrm{I}]$ iodo-2'-deoxyuridine to the nucleus was comparable to that of ${ }^{125} \mathrm{I}$-mAb against cell surface receptors. In vivo, we found that the statistical significance of tumor growth delay induced by ${ }^{125} \mathrm{I}-\mathrm{mAb}$ was removed after MBCD treatment and observed oxidative DNA damage beyond the expected Auger electron range. These results suggest the involvement of nontargeted effects in vivo also. Innovation: Low-energy Auger electrons, such as those emitted by ${ }^{125} \mathrm{I}$, have a short tissue range and are usually targeted to the nucleus to maximize their cytotoxicity. In this study, we show that targeting the cancer cell surface with ${ }^{125} \mathrm{I}$-mAbs produces a lipid raft-mediated nontargeted response that compensates for the inferior efficacy of non-nuclear targeting. Conclusion: Our findings describe the mechanisms involved in the efficacy of ${ }^{125} \mathrm{I}-\mathrm{mAbs}$ targeting the cancer cell surface. Antioxid. Redox Signal. 25, 467-484.
\end{abstract}

\section{Introduction}

$\mathbf{T}$ The highly localized cytotoxicity of Auger electrons is particularly attractive for targeted radionuclide therapy of microscopic or metastatic disease because it allows the irradiation of tumor cells while sparing healthy tissues. Auger electrons are produced in atoms decaying by internal conversion or electron capture. These processes create a vacancy in the inner electron shell that is subsequently filled by electrons dropping in from higher energy levels. Thus, the vacancy moves to the outer shells, and the transition is accompanied by cascades of complex emissions of Auger, Coster-Kronig, and super Coster-Kronig electrons (collectively called Auger electrons) and soft X-rays [for

\footnotetext{
${ }^{1}$ Institut de Recherche en Cancérologie de Montpellier (IRCM), Montpellier, France.

${ }^{2}$ INSERM, U1194, Montpellier, France.

${ }^{3}$ Université de Montpellier, Montpellier, France.

${ }^{4}$ Institut régional du Cancer de Montpellier, Montpellier, France.

${ }_{6}^{5}$ Barts Cancer Institute, Queen Mary University of London, London, United Kingdom.

${ }^{6}$ Institute of Cancer Sciences, University of Glasgow, Glasgow, Scotland.
}

(C) Salomé Paillas, et al., 2016; Published by Mary Ann Liebert, Inc. This Open Access article is distributed under the terms of the Creative Commons Attribution Noncommercial License (http://creativecommons.org/licenses/by-nc/4.0/) which permits any noncommercial use, distribution, and reproduction in any medium, provided the original author(s) and the source are credited. 


\section{Innovation}

Because of their physical properties, Auger electron emitters, such as iodine $125\left({ }^{125} \mathrm{I}\right)$, are usually targeted to the nucleus to maximize their cytotoxicity. In this study, we show that monoclonal antibodies labeled with ${ }^{125} \mathrm{I}$ $\left({ }^{125} \mathrm{I}-\mathrm{mAbs}\right)$ and targeting the cell membrane are cytotoxic through oxidative stress-mediated nontargeted effects. As this nontargeted response is comparable to that observed with ${ }^{125}$ IdUrd, bystander effects induced by cell membrane irradiation could compensate for the anticipated inferior efficacy of the absence of nuclear targeting, particularly when vectors do not gain access to every tumor cell. Furthermore, Auger emitter-labeled mAbs bypass the disadvantages of using labeled deoxyribonucleotides.

review, Kassis (25)]. The majority of Auger electrons have very low energies (between a few eV and $1 \mathrm{keV}$ ) and thus very short range in tissue $(<1 \mu \mathrm{m})$. They release high amounts of energy in a spherical volume of a few cubic nanometers $(46,49,54)$ and behave like medium-to-high linear energy transfer (LET) radiation $(4-26 \mathrm{keV} / \mu \mathrm{m})$. Hence, they produce locally dense ionizations that are very destructive when incorporated into nuclear DNA (7, 22, 26-29) or the nucleus (1, $9,12,14,15)$. Although they have high LET features, they have been shown to contribute to cytotoxicity or DNA lesion formation indirectly via reactive oxygen species (ROS) $(63,64)$.

The radionuclides iodine $125\left({ }^{125} \mathrm{I}\right)$, iodine $123\left({ }^{123} \mathrm{I}\right)$, and indium 111 ( ${ }^{111}$ In) are the most widely used Auger electron emitters for in vitro and in vivo studies. Clinical trials have evaluated the efficacy, toxicity, or tumor distribution of Auger electron emitters conjugated to (i) thymidine analogs that are incorporated into the DNA of cells in S phase $(18,40,41)$, (ii) octreotide, a somatostatin analog targeting neuroendocrine and other cancers $(16,31,37)$, and (iii) monoclonal antibodies (mAbs) with specificity for cancer cellular antigens $(35,52$, 65 ) and human epidermal growth factor receptor (62). The latter treatment is known as radioimmunotherapy (RIT).

Conventionally, Auger electron emitters are targeted to the nucleus or DNA because it is considered that Auger electrons need to be within the nucleus to achieve maximal cell kill. Therefore, RIT using Auger electron emitters has been regarded as comparatively disadvantageous because the localization of the radionuclide, after receptor binding, is not the nucleus, but the cytoplasm (internalizing mAbs) or the cell membrane (noninternalizing mAbs).

However, we previously showed, using in vitro and in vivo models, substantial antitumor efficacy of noninternalizing monoclonal antibodies labeled with ${ }^{125} \mathrm{I}$ ( $\left.{ }^{125} \mathrm{I}-\mathrm{mAbs}\right)$. Furthermore, the cytotoxicity of noninternalizing mAbs was greater than that achieved by internalizing ${ }^{125} \mathrm{I}$-mAbs $(50,53)$ and was not due to inefficient detection of DNA damage related to low absorbed dosage. We proposed that, instead, nontargeted effects could be involved (48). This is in agreement with the work by Xue et al. in 2002 showing in vivo that nontargeted effects are produced by LS174T cells radiolabeled with the DNA base analog 5-[(125)I]iodo-2'deoxyuridine $\left({ }^{125} \mathrm{I}-\mathrm{UdR}\right)$, indicating that Auger electrons can kill cells beyond their path length (66). Other reports indicate that they have also been observed during radionuclide therapy using tritiated thymidine (3H3H-dThd) (5), meta- $\left[{ }^{211} \mathrm{At}\right]$ astatobenzylguanidine $\left({ }^{211} \mathrm{At}-\mathrm{MABG}\right)$, meta $\left[{ }^{123} \mathrm{I}\right]$ iodobenzylguanidine ( $\left.{ }^{123} \mathrm{I}-\mathrm{MIBG}\right)(6)$, and ${ }^{213} \mathrm{Bi}-\mathrm{mAbs}(10)$.

Radiation-induced nontargeted effects (also called bystander effects) occur in cells that are not directly traversed by ionizing particles, but are in contact with irradiated cells. They have been mainly observed after low-dose $(<0.5 \mathrm{~Gy})$ external beam radiotherapy (EBRT), for both low and high LET irradiation, and are associated with a lack of dose-effect relationships [for reviews, Hamada (19) and Prise and O'Sullivan (51)]. Bystander effects include cell death, DNA damage, apoptosis (39), yield of micronuclei and chromosomal aberrations $(4,43)$, and malignant transformation (55). The bystander response depends both on the cell type and on radiation LET and involves the release of soluble factors in the extracellular environment together with the transmission of signaling molecules through gap junctions when cells are in contact $(33,42)$. ROS and reactive nitrogen species (RNS), $\mathrm{Ca}^{2+}$ ions, ATP, and cytokines have been shown to be involved $(2,38)$.

In this study, we show that oxidative stress-induced nontargeted effects are involved in the cytotoxicity of ${ }^{125} \mathrm{I}-\mathrm{mAbs}$ targeting cell surface receptors. This phenomenon involves lipid raft formation followed by subsequent activation of signaling pathways. Moreover, the potency of the cytotoxic nontargeted effect induced by targeting the nucleus with ${ }^{125} \mathrm{I}$ UdR was comparable to that resulting from exposure to ${ }^{125} \mathrm{I}-$ mAbs against cell surface receptors, suggesting that it was independent of the localization of Auger electron emitters. Finally, our data support the existence of nontargeted cytotoxic effects, both in vitro and in vivo.

\section{Results}

\section{${ }^{125}$ I-mAbs induce nontargeted effects}

Clonogenic survival of $p 53^{+/+}$HCT116 cells targeted by $4 \mathrm{MBq} / \mathrm{ml}$ of noninternalizing anti-carcinoembryonic antigen (CEA) ${ }^{125} \mathrm{I}-\mathrm{mAb}$ (resulting in cell surface localization of ${ }^{125} \mathrm{I}$ ) or internalizing anti-Human Epidermal Receptor type 1 (HER1) ${ }^{125} \mathrm{I}-\mathrm{mAb}$ (resulting in cytoplasmic localization of ${ }^{125} \mathrm{I}$ ) (donor cells) was reduced to $58 \% \pm 2.5 \%$ and $57.8 \% \pm 7 \%$, respectively. These values were significantly different $(p<0.001)$ from values measured using the nonspecific ${ }^{125} \mathrm{I}-\mathrm{PX} \mathrm{mAb}$ (Fig. 1A, left panel). We also investigated the role of p53 by performing the same experiments in $p 53^{-/-}$HCT116 cells and showed a similar reduction in clonogenic survival (to $54.6 \% \pm 1.2 \%$ and $56.5 \% \pm 1.9 \%$, respectively) (Fig. 1B, left panel). Again survival was statistically significantly different from survival measured after nonspecific ${ }^{125} \mathrm{I}-\mathrm{PX} \mathrm{mAb}$ exposure $(p<0.001)$, where no toxicity was observed (Fig. 1B, left panel).

To test whether nontargeted effects were involved in the toxicity induced by ${ }^{125} \mathrm{I}-\mathrm{mAb}$, nonirradiated $p 53^{+/+}$and $p 53^{-/-}$ HCT116 cells (recipient cells) were incubated with medium in which donor cells had been cultured for $2 \mathrm{~h}$ following a 2-day exposure to $4 \mathrm{MBq} / \mathrm{ml}$ of anti-CEA or anti-HER1 ${ }^{125} \mathrm{I}-\mathrm{mAbs}$. Clonogenic survival of recipient cells was significantly reduced when compared to that of cells incubated with medium from cells exposed to nonspecific ${ }^{125} \mathrm{I}-\mathrm{PX} \mathrm{mAb}(p<0.01)$. For example, in $p 53^{+/+}$HCT116 recipient cells, survival decreased to $71.2 \% \pm 7.0 \%$ after incubation with medium from $p 53^{+/+}$ HCT116 donor cells exposed to anti-CEA ${ }^{125} \mathrm{I}-\mathrm{mAb}$ and to $70.6 \% \pm 8.4 \%$ after exposure to medium from cells exposed to anti-HER1 ${ }^{125} \mathrm{I}-\mathrm{mAb}$ (Table 1 and Fig. 1A, right panel). Similarly, in $p 53^{-/-}$HCT116 recipient cells, survival decreased to 
A

FIG. 1. Clonogenic survival. Clonogenic survival was assessed in donor and recipients cells 12 days following either exposure to activities of ${ }^{125} \mathrm{I}-\mathrm{mAbs}$ from 0 to $4 \mathrm{MBq} / \mathrm{ml}$ for 2 days (donor cells) or incubation in culture medium in which donor cells had been cultured for $2 \mathrm{~h}$ (recipient cells). Donor cells were treated with noninternalizing ${ }_{125}^{125}$ I-anti-CEA, internalizing ${ }^{125}$ I-anti-HER1, or nontargeting ${ }^{125} \mathrm{I}$-PX mAbs. Clonogenic survival was measured in (A) p53 $3^{+/+}$HCT116, (B) $\mathrm{p} 53^{--}$ HCT116, and (C) A-431 CEA cells. Results are the mean \pm $\mathrm{SD}$ of four experiments performed in triplicate. ${ }^{*} p<0.05$, $* * p<0.01, * * * p<0.001 \mathrm{com}-$ pared with ${ }^{125}$ I-PX mAbtreated cells. CEA, carcinoembryonic antigen; HER1, Human Epidermal Receptor type $1 ;{ }^{125}$ I, iodine $125 ; \mathrm{mAbs}$, monoclonal antibodies; SD, standard deviation.

B
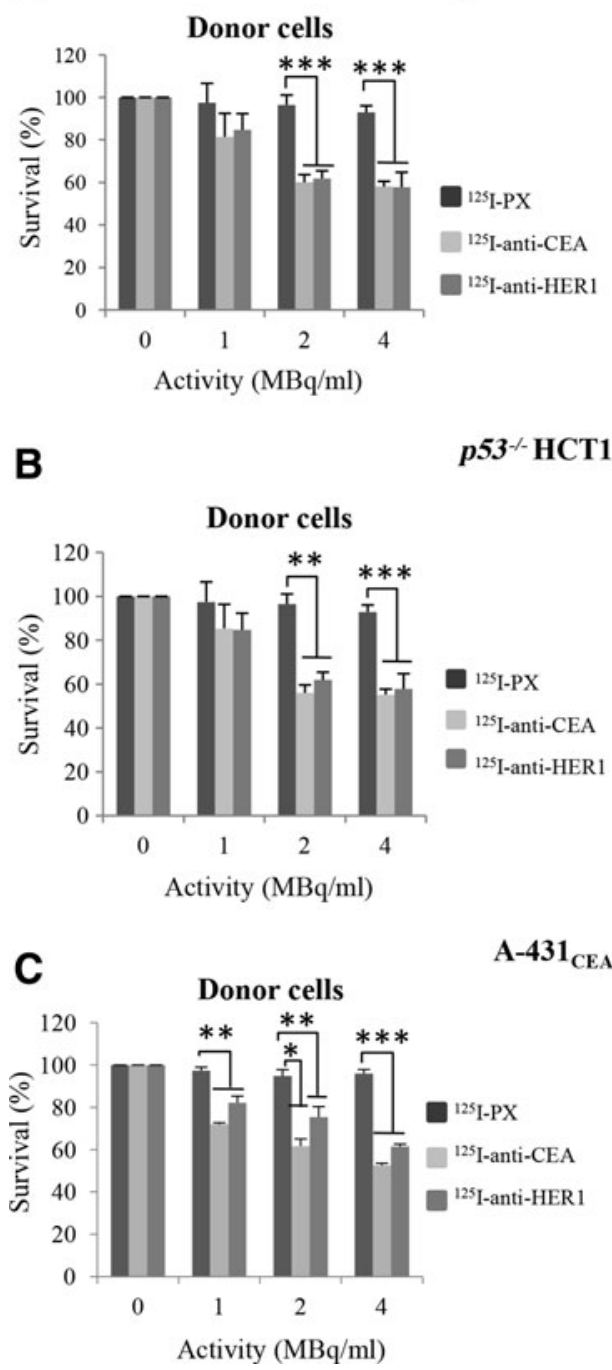

${ }^{p 53^{+/+}}$HCT116 cells

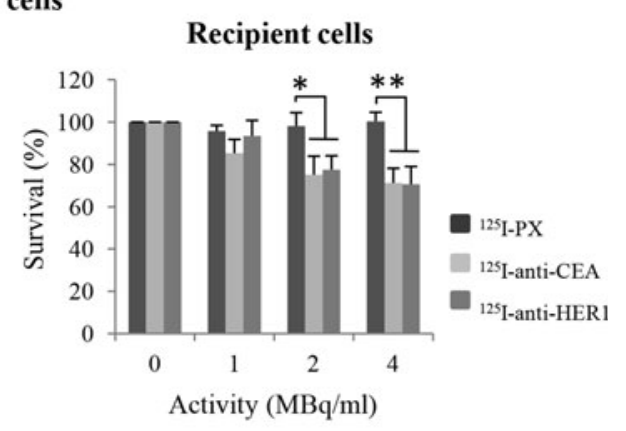

Recipient cells
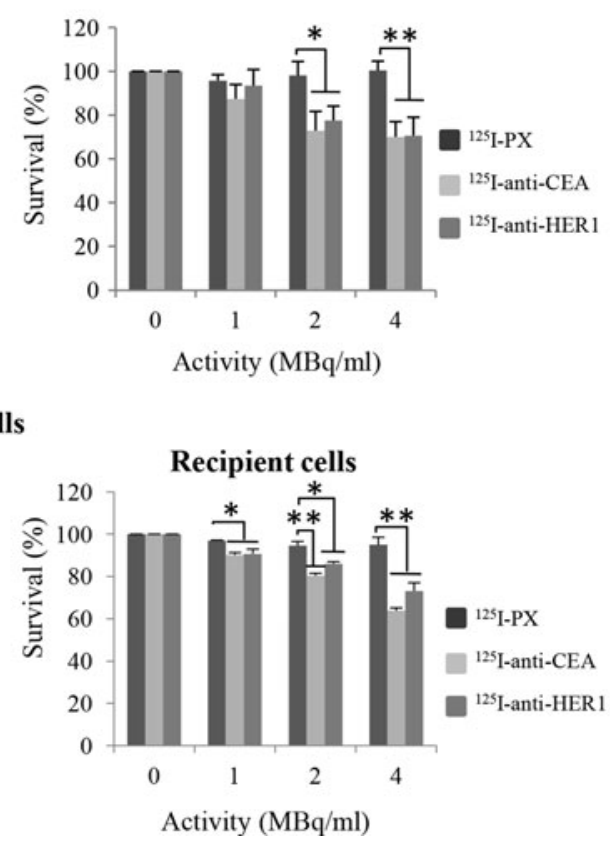

$73.3 \% \pm 5.6 \%$ following incubation with medium from $p 53^{-/-}$ HCT116 donor cells exposed to anti-CEA ${ }^{125} \mathrm{I}-\mathrm{mAb}$ and to $74.5 \% \pm 5.1 \%$ upon switch to medium from cells exposed to anti-HER1 ${ }^{125} \mathrm{I}-\mathrm{mAb}$ (Fig. 1B, right panel).

No cell killing was observed after incubation of recipient cells with medium from donor cells treated with the nontargeting ${ }^{125} \mathrm{I}-\mathrm{PX} \mathrm{mAb}$ (Fig. 1B, right panel) or with unlabeled mAbs (Supplementary Fig. S1A; Supplementary Data are available online at www.liebertpub.com/ars). This suggests that the effect was specific and required ${ }^{125} \mathrm{I}-\mathrm{mAb}$ binding to the cell surface. Similar results were obtained in A-431 CEA (Fig. 1C) and SK-OV-3 $3_{\text {CEA }}$ cells (Supplementary Fig. S1B) treated with the same ${ }^{125}$ I-mAbs. Gamma-H2AX foci (markers of DNA double strand breaks, DSBs) were detected in both $p 53^{+/+}$ HCT116 donor (exposed to anti-CEA or anti-HER $1{ }^{125} \mathrm{I}-\mathrm{mAbs}$ ) and recipient cells, again indicating the occurrence of nontargeted effects in recipient cells (Fig. 2A, B). It must be noted that cells were proliferating and that a larger number of gammaH2AX foci are likely to be produced during the $\mathrm{S}$ phase. The proportion of donor cells showing foci was assessed to be about $10 \%$ in nonirradiated cells, while it increased up to $25 \%$ in cells exposed to the nonspecific ${ }^{125} \mathrm{I}-\mathrm{PX} \mathrm{mAb}$ and $100 \%$ after exposure to the specific anti-HER 1 and anti-CEA ${ }^{125} \mathrm{I}$-mAbs.
Corresponding values were $15 \%$ and $100 \%$ in recipient cells (data not shown).

\section{Nontargeted effects do not require cellular internalization of ${ }^{125}$,}

Localization of the anti-CEA and anti-HER1 mAbs at the cell membrane and cytoplasm, respectively, was confirmed by cell fractionation followed by Western blotting (Fig. 2C) and by immunofluorescence (Fig. 2D) in $p 53^{+/+} \mathrm{HCT} 116$ and A- $431_{\text {CEA }}$ cells. Coincubation of $p 53^{+/+}$HCT116 donor cells with anti-CEA or anti-HER $1{ }^{125}$ I-mAbs and sodium azide, a drug preventing antibody internalization after receptor binding, did not modify the nontargeted response in recipient cells (Fig. 2E). These results suggest that internalization of ${ }^{125} \mathrm{I}$ is not required for radiation-induced nontargeted effects.

\section{The role of lipid rafts in ${ }^{125}$ I-mAb cytotoxicity in vitro}

Lipid rafts can be ceramide-enriched platforms in the cell membrane that are produced through sphingomyelin hydrolysis to ceramide and phosphorylcholine following acid sphingomyelinase (ASMase) activation by ROS (56). To investigate whether ${ }^{125} \mathrm{I}-\mathrm{mAbs}$ affected the cell membrane 


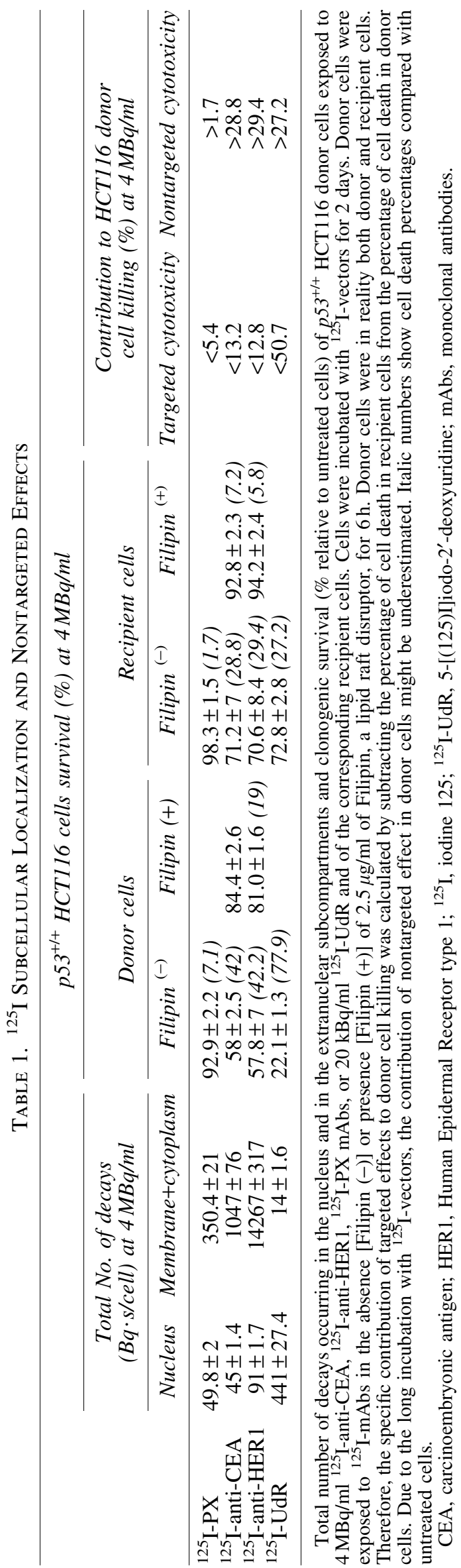

organization, the formation of lipid raft domains, as detected by cholera toxin, was monitored in donor $p 53^{+/+}$HCT116 cells exposed to $4 \mathrm{MBq} / \mathrm{ml}$ of anti-CEA or anti-HER $1{ }^{125} \mathrm{I}-$ $\mathrm{mAbs}$ for $48 \mathrm{~h}$. In these cells, lipid raft formation was increased compared with nonirradiated cells (NT) or with cells incubated with the irrelevant ${ }^{125} \mathrm{I}$-PX mAb (Fig. 3A). Flow cytometric analysis showed that the membrane concentration of ceramide (indicative of lipid raft formation) in cells exposed to anti-CEA or anti-HER1 ${ }^{125}$ I-mAbs was increased compared with nonirradiated cells (NT) and cells treated with unlabeled mAbs (Fig. 3B). Codetection of ceramide and Annexin (apoptosis marker) by immunofluorescence was observed in some of the $\mathrm{p} 53^{+/+}$HCT116 cells (Fig. 3C). However, we previously showed that apoptosis was not involved in the cytotoxic effects of ${ }^{125} \mathrm{I}$-anti-CEA mAb (46).

The formation of ceramide was corroborated also by the significantly higher ASMase activity measured in whole cell lysates of $p 53^{+/+}$HCT116 treated with anti-CEA or antiHER $1{ }^{125}$ I-mAbs (three times higher compared to unlabeled mAbs, $p<0.001$ ) (Fig. 3D). We also found that the level of sphingosine-1-phosphate (S1P) resulting from hydrolysis of ceramide was strongly increased in cells exposed to anti-CEA or anti-HER $1{ }^{125}$ I-mAbs (Fig. 3E), while no such increase was observed in control cells.

The involvement of lipid raft formation in ${ }^{125} \mathrm{I}-\mathrm{mAb}$ cytotoxicity was confirmed by the finding that lipid raft formation was reduced in $p 53^{+/+}$HCT116 donor cells coincubated with anti-CEA or anti-HER1 ${ }^{125} \mathrm{I}-\mathrm{mAbs}$ and filipin (a lipid raft disruptive agent) compared with cells exposed only to ${ }^{125} \mathrm{I}$ mAbs (Fig. 4A). Moreover, coincubation of donor cells with filipin significantly reduced the formation of phosphorylated histone $\mathrm{H} 2 \mathrm{AX}(\gamma-\mathrm{H} 2 \mathrm{AX})$ foci in both donor and recipient cells (Fig. 4B). Finally, ${ }^{125} \mathrm{I}-\mathrm{mAb}$ cytotoxicity in both donor (Fig. 4C) and recipient cells (Fig. 4D) was significantly reduced when donor cells were incubated in the presence of filipin. Indeed, clonogenic survival increased from $58 \% \pm 2.5 \%$ to $84.4 \% \pm 2.6 \%$ and from $57.8 \% \pm 7 \%$ to $81.0 \% \pm 1.6 \%$ in donor cells coincubated with $4 \mathrm{MBq} / \mathrm{ml}$ anti-CEA or anti-HER1 ${ }^{125} \mathrm{I}-$ mAbs and filipin, respectively (Table 1). In recipient cells, survival increased from $71.2 \% \pm 7 \%$ to $92.8 \% \pm 2.3 \%$ and from $70.6 \% \pm 8.4 \%$ to $94.2 \% \pm 2.4 \%$, respectively. Similar protection was afforded by methyl- $\beta$-cyclodextrin (MBCD), another lipid raft disruptor (Supplementary Fig. S2). These findings indicate that lipid raft formation is involved in both targeted and nontargeted cytotoxicity of ${ }^{125} \mathrm{I}-\mathrm{mAbs}$.

\section{Phosphorylated proteins associated with ${ }^{125}$ I-RIT}

To identify the signaling pathways activated in cells exposed to anti-CEA or anti-HER $1{ }^{125}$ I-mAbs, the phosphorylation profiles of 46 kinases were assessed by array-based proteomics (Fig. 5 and Supplementary Fig. S3). Only extracellular signal-related kinase 1/2 (ERK1/2) and C-AMP Response Element-binding protein (CREB) were strongly activated after treatment with unlabeled anti-CEA mAb (Fig. 5A). Conversely, upon incubation with the unlabeled anti-HER $1 \mathrm{mAb}$, several proteins were induced, including ERK1/2, CREB, p53, and AKT (Fig. 5B).

Thus, only the anti-CEA ${ }^{125} \mathrm{I}-\mathrm{mAb}$ was used to investigate the effect of targeting ${ }^{125}$ I to the cell surface. When cells were exposed to anti-CEA ${ }^{125} \mathrm{I}-\mathrm{mAb}$ (Fig. 5A), the ERK1/2, AKT, $\mathrm{p} 38$, and c-Jun $\mathrm{N}$-terminal kinase (JNK) signaling pathways 
FIG. 2. Gamma-H2AX foci detection and optional role of ${ }^{125}$ I-mAb internalization for nontargeted cytotoxicity. (A) Detection of gamma-H2AX foci in $p 53^{+/+}$HCT116 donor (top panels) and recipient cells (bottom panels) by immunofluorescence assay. (B) The number of foci per cell was counted in 100 cells. Antibody localization was assessed in $p 53^{+/+}$HCT116 and A-431 $1_{\text {CEA }}$ cells by (C) subcellular fractionation and (D) immunofluorescence. F-actin was stained with conjugated phalloidin (Red) to visualize cytoplasm, nuclei with Hoechst (Blue), and mAbs with Alexa488-conjugated anti-mouse secondary mAbs. (E) Clonogenic survival was assessed in $p 53^{+/+}$ HCT116 donor cells coincubated with $0.02 \%$ sodium azide (a drug blocking antigen internalization) and a range of activities of ${ }^{125}$ I-mAbs (noninternalizing anti-CEA, internalizing anti-HER1, or nontargeting PX mAbs). Clonogenic survival of recipient cells was assessed after incubation with conditioned medium from donor cells exposed to ${ }^{125} \mathrm{I}-\mathrm{mAbs}$ in the presence of sodium azide. Results are the mean $\pm \mathrm{SD}$ of three experiments performed in triplicate. $* p<0.05,{ }^{* *} p<0.01$, and $* * * p<0.001$ compared to NT cells $(\mathbf{B})$ or to the ${ }^{125}$ I-PX mAb-treated cells (E). Mb, membrane; Cyto, cytoplasm. To see this illustration in color, the reader is referred to the web version of this article at www.liebertpub.com/ars
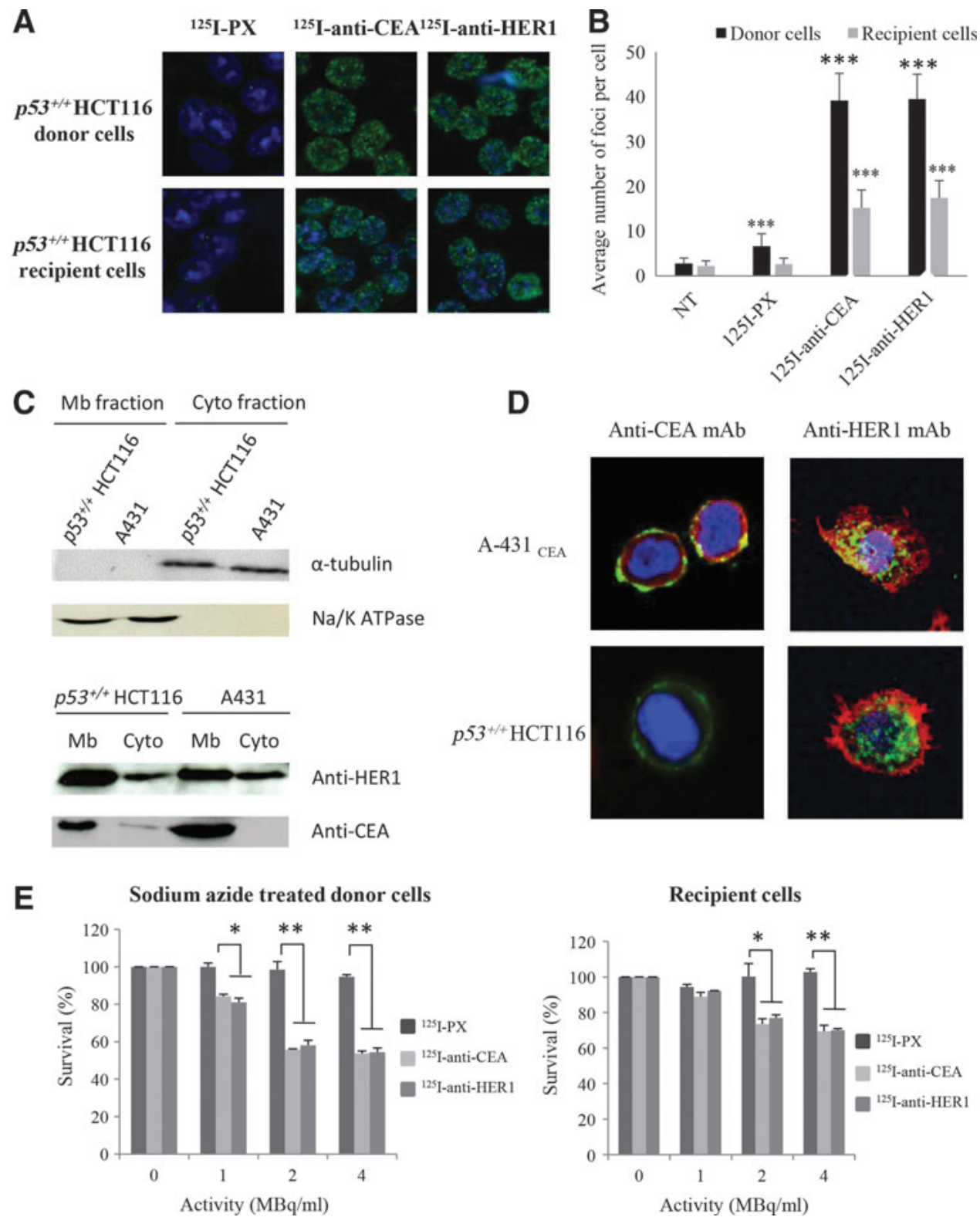

were induced. Activated downstream AKT proteins included p70S6 kinase (p70S6K), glycogen synthase kinase 3 (GSK3), and endothelial nitric oxide synthase (e-NOS) (61). Signal transducer and activator of transcription (STAT) 1 and 4, $90 \mathrm{kDa}$ ribosomal S6 kinase (RSK), mitogen- and stressactivated protein kinase (MSK), and CREB proteins, which are downstream targets of ERK1/2 signaling, were also activated, as well as c-JUN, which is downstream of p38 and JNK (for review (61)). Phosphorylated proteins involved in $\mathrm{Ca}^{2+}$ fluxes, such as phospholipase $\mathrm{C}-\gamma$ (PLC- $\gamma$ ), proline-rich tyrosine kinase 2 (PYK-2), and paxillin, were strongly activated by exposure to anti-CEA ${ }^{125}$ I-mAb. Phosphorylation of AKT, p38, JNK, CREB, GSK3, STAT 1 and 4, e-NOS, MSK, PLC- $\gamma$, PYK-2, and paxillin was abolished, whereas phosphorylation of ERK1/2, c-JUN, p53, RSK, SAT 2, and p70S6K was diminished in cells coincubated with filipin (Fig. 5), confirming that these proteins are downstream ef- fectors of lipid raft formation and, thus, are likely to be involved in ${ }^{125} \mathrm{I}-\mathrm{mAb}$ nontargeted effects. Moreover, the use of different pharmacological inhibitors of MEK (U0126) and subsequently of downstream ERK1/2 signaling pathway, PI3K (ZSTK474) and subsequently of downstream AKT signaling pathway, p38 (SB203580), and JNK (SP600125) indicated that, among the identified proteins activated, p38 and JNK were mainly involved in the response of cells to ${ }^{125} \mathrm{I}$ mAb exposure (Fig. 6). No effect of EGTA on clonogenic survival was observed (Supplementary Fig. S1C).

\section{ROS are involved in Auger electron-induced nontargeted response}

The involvement of ROS in the mediation of the bystander response was examined by culturing recipient cells in medium from $\mathrm{p} 53^{+/+}$HCT116 donor cells that had been treated 

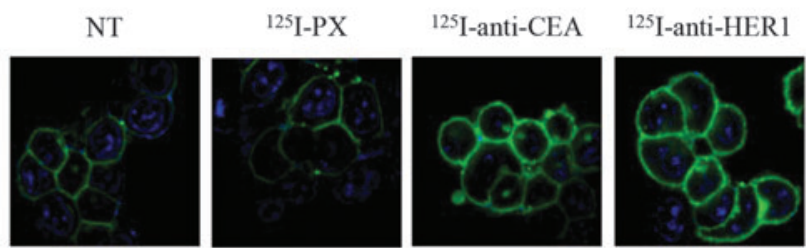

B

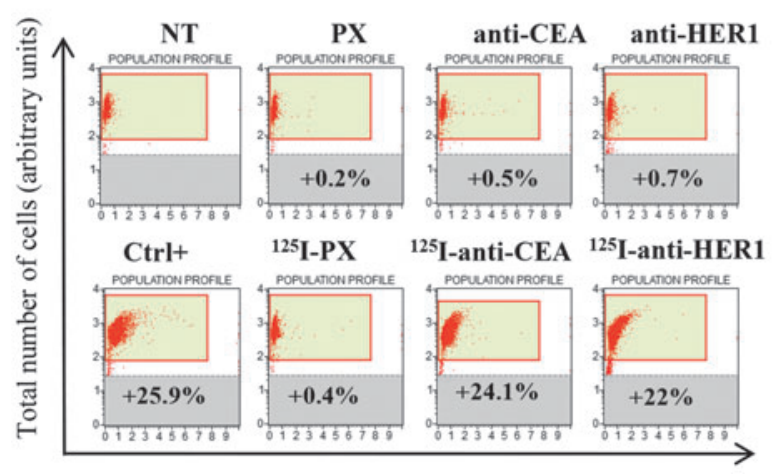

FL1 (PE-conjugated goat mAb anti-ceramide 15B4 mAb)
C
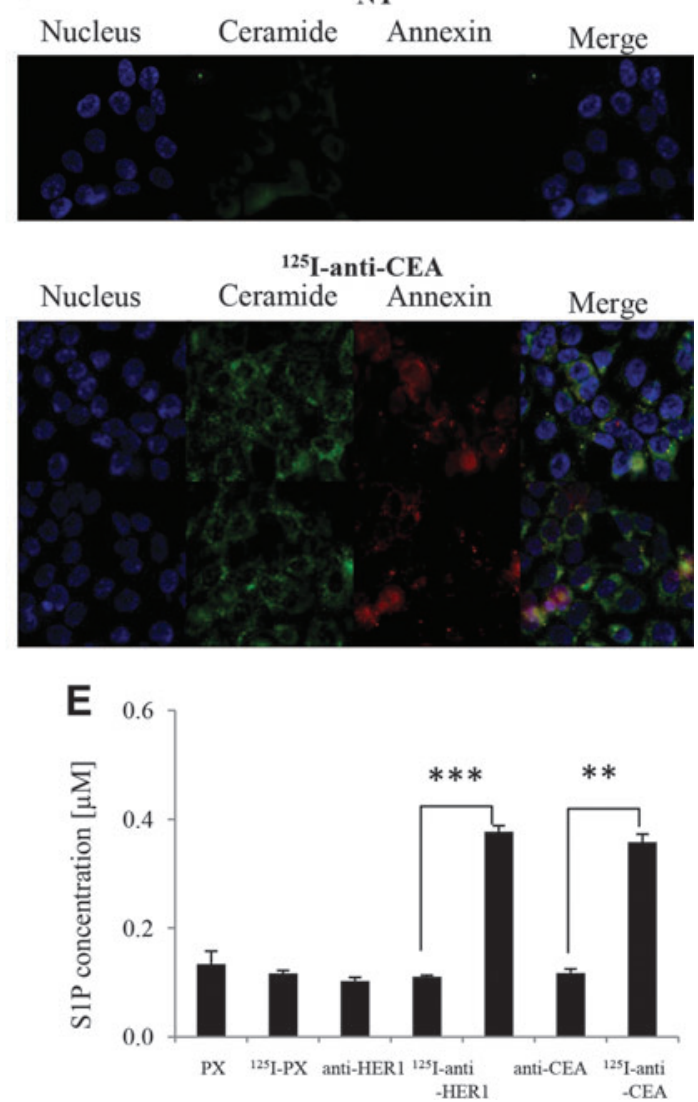

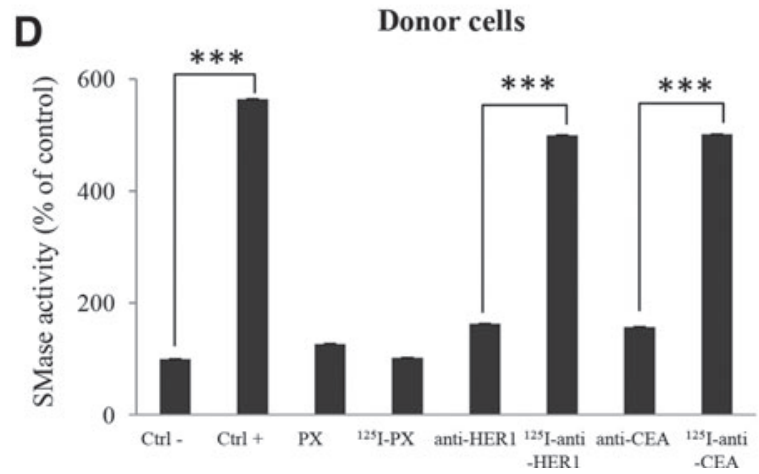

FIG. 3. Lipid rafts are formed upon exposure to ${ }^{125} \mathrm{I}-\mathrm{mAbs}$ via ASMase-induced ceramide formation. (A) Lipid rafts were detected by immunofluorescence analysis using Alexa-488-conjugated cholera toxin (a marker of lipid raft) in untreated (NT) and treated $p 53^{+/+}$HCT116 cells (noninternalizing ${ }^{125} \mathrm{I}$-anti-CEA, internalizing ${ }^{125} \mathrm{I}$-anti-HER1, nontargeting ${ }^{125} \mathrm{I}-\mathrm{PX} \mathrm{mAbs}$ ). (B) Ceramide was measured in $p 53^{+/+}$HCT116 cells by flow cytometry analysis after treatment with unlabeled mAbs (top panels), or with ${ }^{125} \mathrm{I}-\mathrm{mAbs}$ (bottom panels). Ctrl+, positive control (100 $\mu \mathrm{l}$ of $0.4 \mathrm{U} / \mathrm{ml}$ Bacillus cereus SMase and $10 \mu \mathrm{l}$ sphingomyelin). (C) Colocalization of ceramide and Annexin V in apoptotic cells was determined by immunofluorescence, in untreated (NT) and ${ }^{125} \mathrm{I}-$ anti-CEA-treated $p 53^{+/+}$HCT116 cells. (D) ASMase activity was determined in whole $p 53^{+++}$HCT116 cell lysates using the Amplex Red Sphingomyelinase Fluorimetry Kit after incubation with unlabeled or ${ }^{125} \mathrm{I}-\mathrm{mAbs}$. Ctrl+, positive control (100 $\mu \mathrm{l}$ of $0.4 \mathrm{U} / \mathrm{ml} \mathrm{B}$. cereus SMase and $10 \mu \mathrm{l}$ sphingomyelin); Ctrl- (Amplex Red working solution without sphingomyelin). (E) S1P concentration was determined in whole $p 53^{+++}$HCT116 cells lysates using the Sphingosine-1-Phosphate Assay Kit after incubation with unlabeled or ${ }^{125} \mathrm{I}-\mathrm{mAbs}$ or in nontreated cells (NT). Results are the mean $\pm \mathrm{SD}$ of four experiments performed in triplicate. $* * p<0.01$ and $* * * p<0.001$ compared to cells treated with unlabeled mAbs. ASMase, acid sphingomyelinase; S1P, sphingosine-1phosphate. To see this illustration in color, the reader is referred to the web version of this article at www.liebertpub.com/ars

with ${ }^{125} \mathrm{I}-\mathrm{mAbs}$ in the presence or absence of the free radical scavengers dimethyl sulfoxide (DMSO) or N-acetylcysteine (NAC) (Fig. 7). We previously checked (using immunofluorescence detection of mAbs in the presence of cells grown on coverslips) that NAC did not prevent anti-HER1 or antiCEA mAbs from binding to their receptors.

Survival of both donor and recipient cells was significantly increased compared with controls treated with ${ }^{125} \mathrm{I}-\mathrm{mAbs}$ in the absence of free radical scavengers $(p<0.001$ and $p<0.01$, respectively). This suggests that oxidative stress is involved in both targeted and nontargeted cytotoxic effects of ${ }^{125} \mathrm{I}-\mathrm{mAbs}$.

\section{Nontargeted effects of ${ }^{125}$ I directed to the cell membrane or the nucleus are equipotent}

To compare the effect of targeting ${ }^{125}$ I to the cell membrane or the nucleus, $p 53^{+/+}$HCT116 donor cells were incubated with ${ }^{125} \mathrm{I}-$ UdR (nuclear localization of ${ }^{125} \mathrm{I}$ ) or with anti-CEA or anti-HER1 


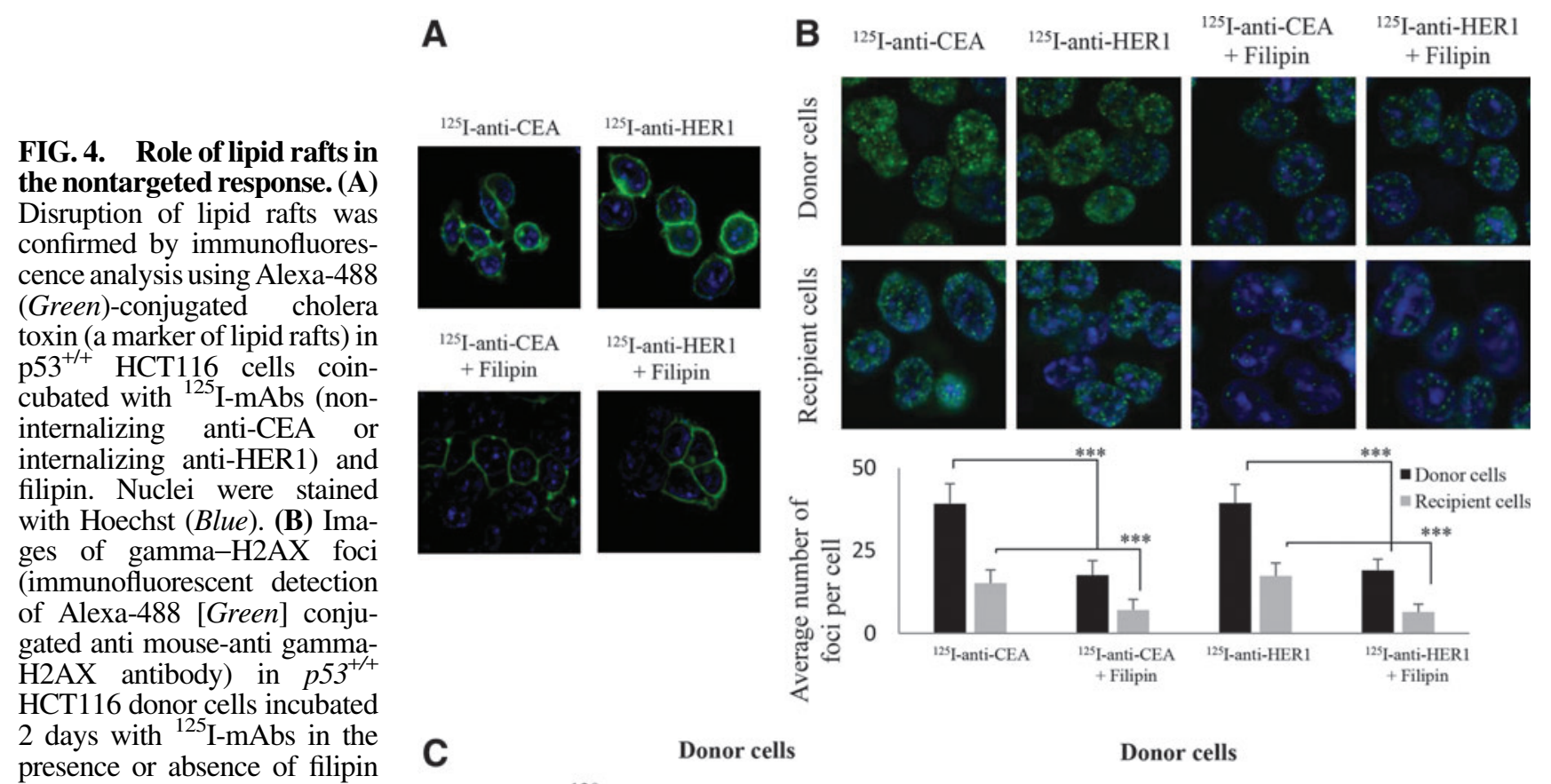
(top panels) and in the corresponding recipient cells (bottom panels). The number of foci per cell was counted in 100 cells. Clonogenic survival was assessed in $p 53^{+/+}$HCT116 donor cells coincubated for 2 days with and without ${ }^{125} \mathrm{I}$ mAbs and filipin (C), and in the corresponding recipient cells (D). Results are the mean \pm SD of four experiments performed in triplicate. ${ }^{*} p<0.05, * * p<$ $0.01,{ }^{* * *} p<0.001$ compared to cells treated with ${ }^{125} \mathrm{I}-\mathrm{mAbs}$. To see this illustration in color, the reader is referred to the web version of this article at www.liebertpub.com/ars
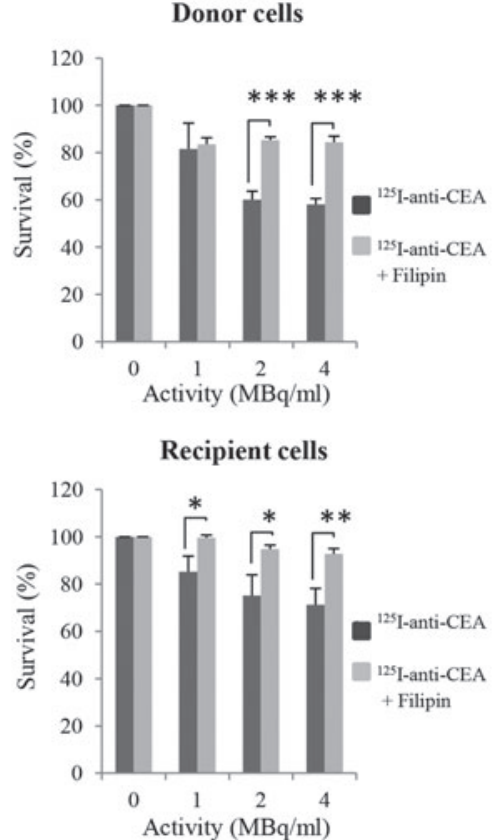
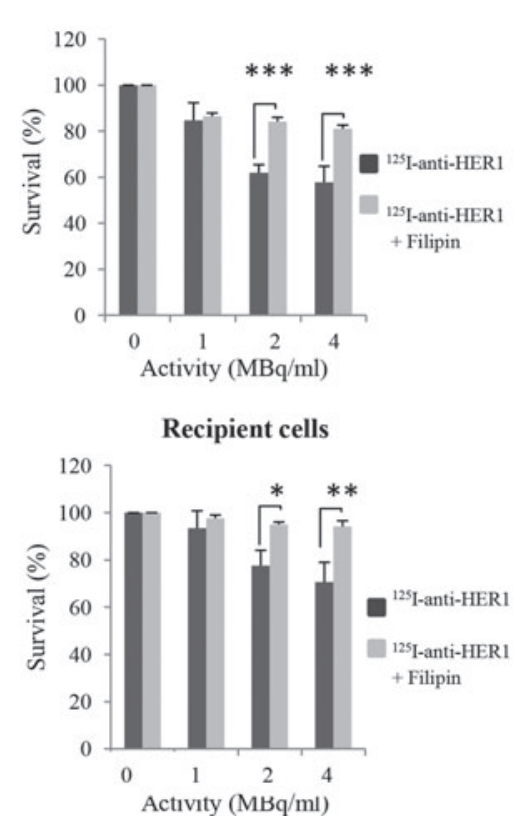

${ }^{125}$ I-mAbs. Subsequently, clonogenic survival was assessed in both donor and recipient cells. Results are summarized in Table 1. The uptake of ${ }^{125} \mathrm{I}-\mathrm{UdR}$ and ${ }^{125} \mathrm{I}-\mathrm{mAbs}$ was measured for every test activity for 6 days, and the total number of decays occurring in cells was calculated as described previously (46). The results of the clonogenic survival assay showed that, in donor cells, ${ }^{125} \mathrm{I}-\mathrm{UdR}$ (nuclear localization) was more cytotoxic than anti-CEA (cell surface localization) or anti-HER1 (cytoplasm localization) ${ }^{125} \mathrm{I}$ mAbs. Conversely, in recipient cells, cell survival was similar and independent of ${ }^{125} \mathrm{I}$ localization, indicating that ${ }^{125} \mathrm{I}$ at the cell membrane is as efficient as nuclear ${ }^{125} \mathrm{I}$ in killing bystander cells.

\section{The role of lipid rafts in ${ }^{125} /$-mAb cytotoxicity in vivo}

Mice bearing intraperitoneal tumor xenografts were treated with $\mathrm{NaCl}$, anti-CEA mAb $(100 \mu \mathrm{g} /$ injection at day 8 and 11$)$, ${ }^{125} \mathrm{I}$-anti-CEA mAb (37 MBq/injection at day 8 and 11$)$, or
MBCD (300 mg/kg; daily, from day 6 to 15$)$, or with both ${ }^{125} \mathrm{I}-$ anti-CEA $\mathrm{mAb}$ and MBCD. At day 30, tumor mass was significantly reduced in the group treated with ${ }^{125} \mathrm{I}$-anti-CEA mAb (RIT) compared with the $\mathrm{NaCl}$ group ( $p=0.0227$ ). No difference was observed between the groups treated with $\mathrm{MBCD}, \mathrm{NaCl}$ $(p=0.9349)$, or anti-CEA mAb $(p=0.9563)$. The latter result is in agreement with a previously published study indicating that antiCEA mAbs have no effect on mouse tumor growth (53). Treatment with MBCD removed the statistical significance of RITinduced tumor growth delay such that no difference was observed between $\mathrm{NaCl}$ and $\mathrm{RIT}+\mathrm{MBCD}$ groups $(p=0.2481)$ (Fig. 8A).

\section{Oxidative DNA damage occurs beyond the range of Auger electrons in vivo}

Digital autoradiographic analysis performed on sections of tumors collected in mice injected with ${ }^{125} \mathrm{I}$-anti-CEA mAb 
A
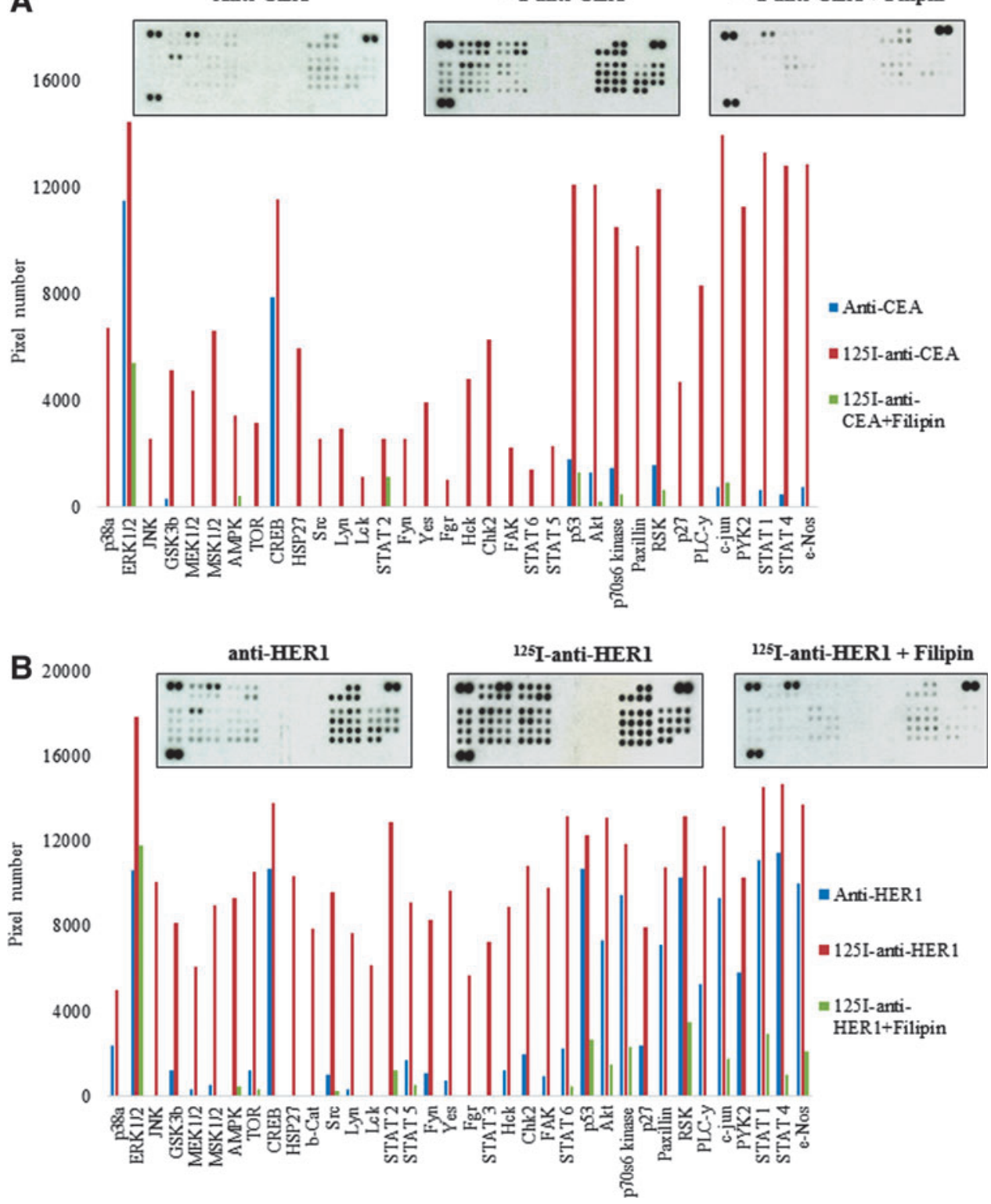

FIG. 5. Signaling pathways activated in ${ }^{125} \mathrm{I}-\mathrm{mAb}$ treated $\mathrm{p53}^{+/+}$HCT116 cells and role of oxidative stress in the nontargeted response. (A) Signaling pathways activated after incubation of $p 53^{+/}$ + HCT116 donor cells with unlabeled anti-CEA, anti-CEA ${ }^{125}$ I-mAbs, or anti-CEA ${ }^{125}$ ImAbs and filipin. (B) Signaling pathways activated after incubation of $p 53^{+/+}$HCT116 donor cells with unlabeled anti-HER1, anti-HER1 ${ }^{125}$ ImAbs, or anti-HER1 ${ }^{125} \mathrm{I}$ $\mathrm{mAbs}$ and filipin. The Human Phospho-Kinase array (Proteome Profiler Array; R\&D Systems, Minneapolis, MN) was used to detect the phosphorylation level of 46 kinases. For each kinase, the Image $\mathbf{J}$ software was used to determine pixel number. To see this illustration in color, the reader is referred to the web version of this article at www.liebertpub.com/ars showed that radioactivity (and thus the absorbed dose) was mainly localized at the tumor periphery in A-431 $1_{\text {CEA }}$ tumor cell xenografts (Fig. 9A, inset in the bottom left corner). Conversely, DNA DSBs occurred homogeneously throughout the tumor, as indicated by immunofluorescence detection of p53-binding protein 1 (53BP1), a DNA damage sensor that is recruited to damaged chromatin (Fig. 9A). The average number of foci per cell was 4.4 at the center and 4.3 at the periphery of the tumor. The corresponding regional activities were 2.3 and $34.7 \mathrm{cpm}$ per $\mathrm{mm}^{2}$. Our observation of similar levels of DNA DSBs at the center of the tumor, independent of the absorbed dose and beyond the range of Auger electrons, supports the involvement of nontargeted effects also in vivo. 53BP1 expression was also investigated in A-431 $1_{\text {CEA }}$ tumor cell xenograft sections from mice injected with the irrelevant ${ }^{125} \mathrm{I}-\mathrm{PX} \mathrm{mAb}$ (Fig. 9B). The numbers of foci per cell was 0.8 (tumor center) and 1.0 (tumor periphery). These values were lower than those observed following treatment with anti-CEA ${ }^{125} \mathrm{I}-\mathrm{mAb}$, de- spite the higher uptake of ${ }^{125} \mathrm{I}-\mathrm{PX} \mathrm{mAb}$ exemplified by activity per area values of 28 and $18.2 \mathrm{cpm} / \mathrm{mm}^{2}$ at the tumor center and periphery, respectively. A similar level of $0.7 \pm \pm 0.153 \mathrm{BP} 1$ foci was found in tumors of $\mathrm{NaCl}$ or antiCEA-treated mice (Fig. 9C).

This ruled out the possibility that the signal detected in tumors treated with anti-CEA ${ }^{125} \mathrm{I}-\mathrm{mAb}$ was caused by nonspecific induction of 53BP1 due to cross-irradiation from the radioactivity present in nonmalignant regions of the animal.

\section{Discussion}

In the present study, we show that ${ }^{125}$ I translocation to the nucleus is not required for cell killing and that radiationinduced nontargeted effects contribute to ${ }^{125}$ I cytotoxicity when labeled with monoclonal antibodies $\left({ }^{125} \mathrm{I}-\mathrm{mAbs}\right)$ (Table 1). We also identify the signaling pathways involved in these nontargeted effects. In particular, we show using $\mathrm{p} 53^{-1-}$ and $\mathrm{p} 53^{+/+}$HCT116 cells that the latter protein did not play a 

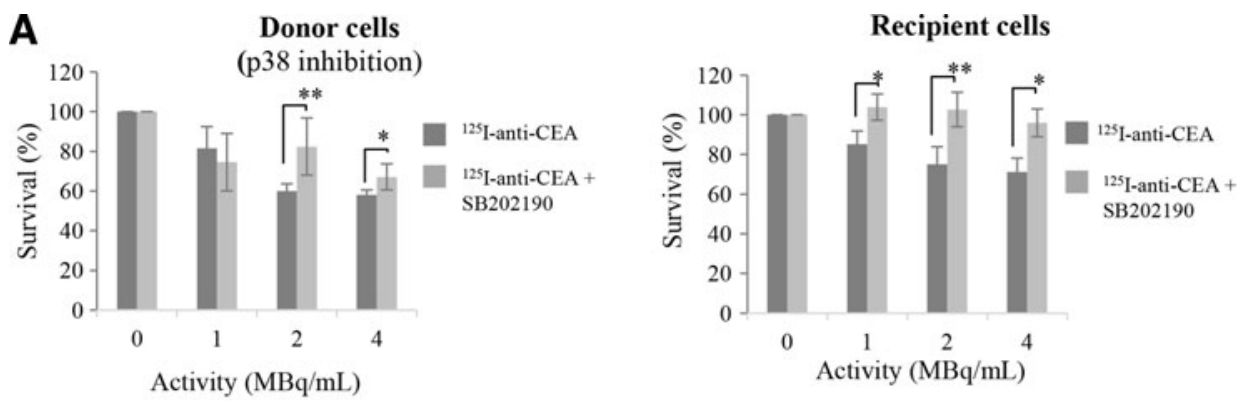

FIG. 6. Pharmacological inhibitors of MAPK pathways. $p 53^{+/+} \mathrm{HCT} 116$ donor cells were incubated for $48 \mathrm{~h}$ with ${ }^{125} \mathrm{I}$-anti-CEA $\mathrm{mAb}$ in the presence of (A) SB203580 (p38 inhibitor), (B) SP600125 (JNK inhibitor), (C) ZSTK474 (PI3K inhibitor and indirectly of its downstream AKT pathway), or (D) U0126 (MEK1/2 inhibitor and indirectly of its downstream ERK1/2 pathway). Results are the mean \pm SD of four experiments performed in triplicate. ${ }^{*} p<0.05$, $* * p<0.01$, compared to cells treated with ${ }^{125} \mathrm{I}-\mathrm{mAbs}$. ERK1/ 2 , extracellular signal-related kinase $1 / 2$; JNK, c-Jun Nterminal kinase; MAPK, mitogen-activated protein kinase.
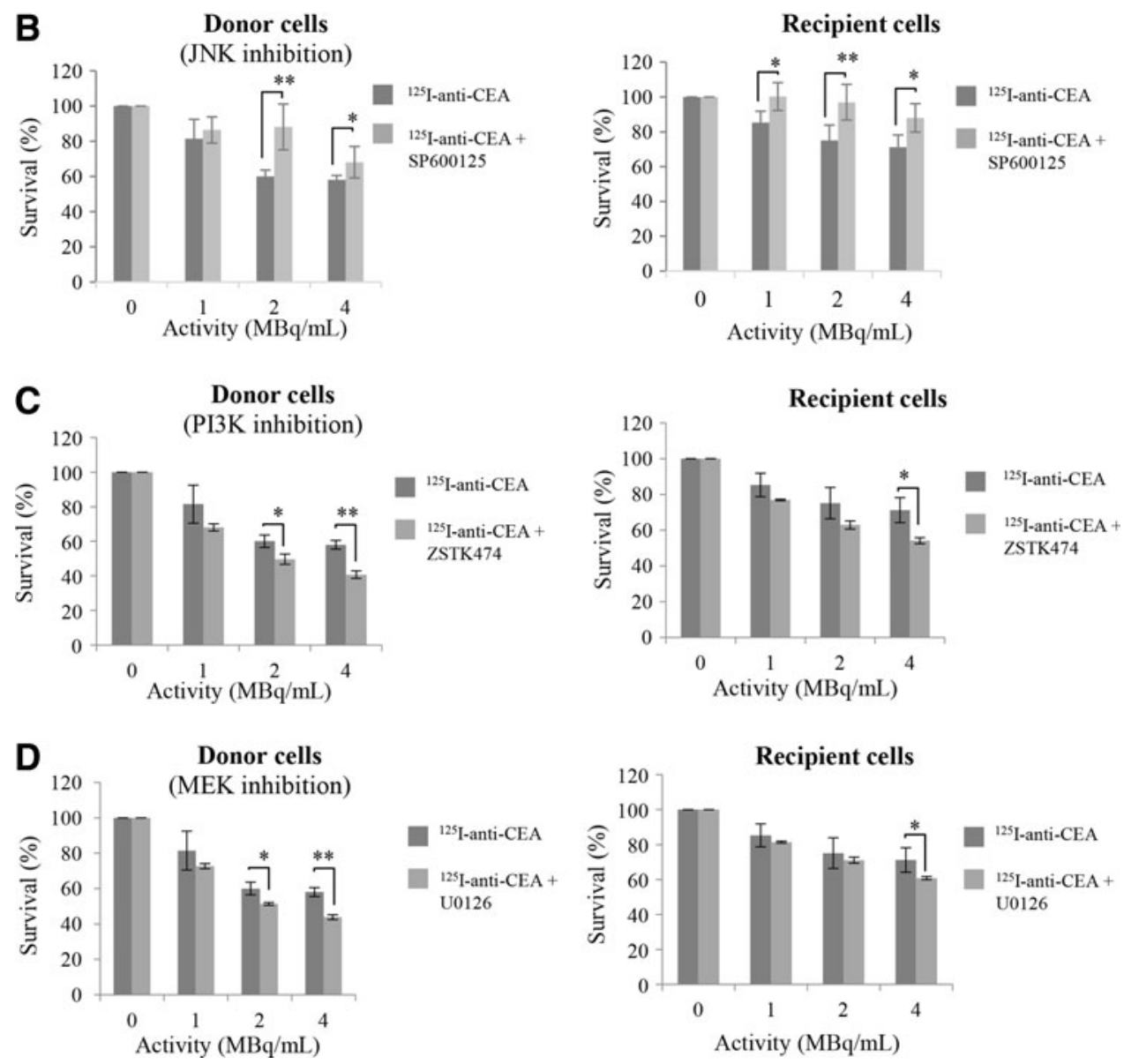

significant role in anti-CEA ${ }^{125} \mathrm{I}$-mAb cytotoxicity since no difference was observed between the two cell lines (Fig. 1A, B and Supplementary Fig. S4). We chose the nuclear p53 protein as it is one of the main proteins involved in signaling pathways activated by nuclear damage.

The potency of nontargeted cell kill, assessed using a medium transfer protocol, was independent of ${ }^{125}$ I localization (nucleus, cytoplasm, or cell surface) and of the magnitude of targeted cytotoxicity in donor cells (Table 1). In our in vitro experimental RIT model, donor cells were incubated with ${ }^{125}$ I-mAbs and were killed both by targeted and nontargeted effects. Therefore, it is possible to determine the relative contribution of targeted and nontargeted cytotoxicity to donor cells by comparing the survival values of donor and recipient cells reported in Table 1. As death of recipient cells (incubated in culture medium in which donor cells had been cultured for $2 \mathrm{~h}$ ) ranged between $28.8 \%$ and $29.4 \%$ (Fig. 1B), it may be assumed that a similar (or even higher) magnitude of nontargeted effects also occurred in donor cells that were directly exposed to ${ }^{125} \mathrm{I}-\mathrm{mAbs}$ for $48 \mathrm{~h}$. Accordingly, cell death by targeted effects in donor cells would be equal to or less than $13.2 \%$ (42.0\% minus $28.8 \%$ ) and $12.8 \%(42.2 \%$ minus $29.4 \%$ ) for ${ }^{125} \mathrm{I}$ localized at the cell surface or cytoplasm, respectively, and equal to or less than $50.7 \%$ (77.9\% minus $27.2 \%$ ) for ${ }^{125}$ I within the nucleus (Table 1). These data confirm the greater cytotoxicity of ${ }^{125}$ I when incorporated into DNA $(22,17,64)$ in cells that are directly targeted.

Our results indicate that the cell membrane plays a major role not only in the targeted cytotoxic effects of ${ }^{125} \mathrm{I}-\mathrm{mAbs}$ but also in nontargeted cytotoxic effects (Fig. 1). According to the fluid mosaic model (57), the membrane contains sphingolipids (predominantly sphingomyelin), cholesterol, and glycophospholipids. Sphingolipids associate with each other and with cholesterol to form sphingolipid- and 

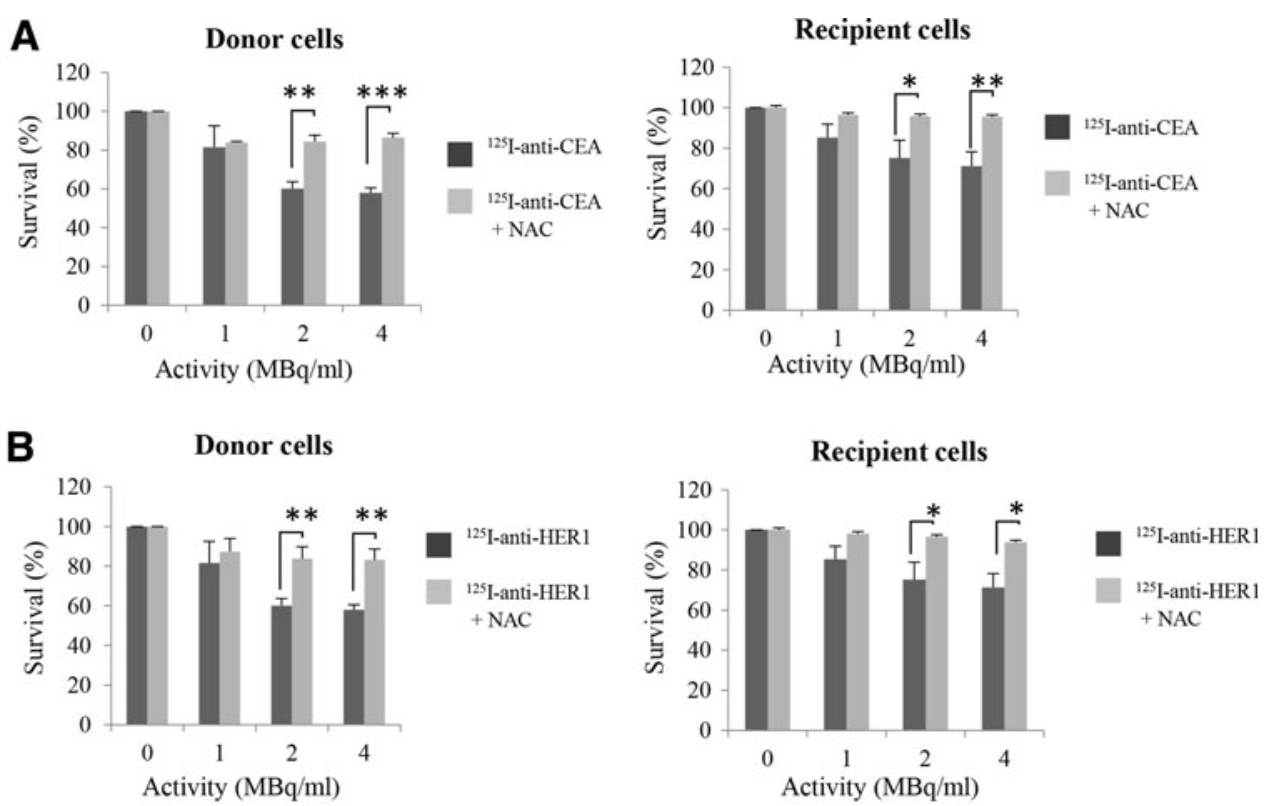

FIG. 7. Oxidative stress is involved in direct and nontargeted cytotoxicity: Effect of NAC on RIT-induced effects. $p 53^{+/+}$HCT116 donor cells were coincubated for 2 days with $50 \mu M$ NAC or $0.5 \%$ DMSO and ${ }^{125}$ I-antiCEA (A, C, respectively) or ${ }^{125}$ I-anti-HER1 (B, D, respectively) mAbs. Clonogenic survival of the donor cells and of the corresponding recipient cells was measured. Results are the mean $\pm S D$ of four experiments performed in triplicate. $*_{p} p<0.05, \quad * * p<0.01$, $* * * p<0.001$ compared to cells treated with ${ }^{125} \mathrm{I}$-mAbs. DMSO, dimethyl sulfoxide; NAC, N-acetyl-L-cysteine; RIT, radioimmunotherapy.
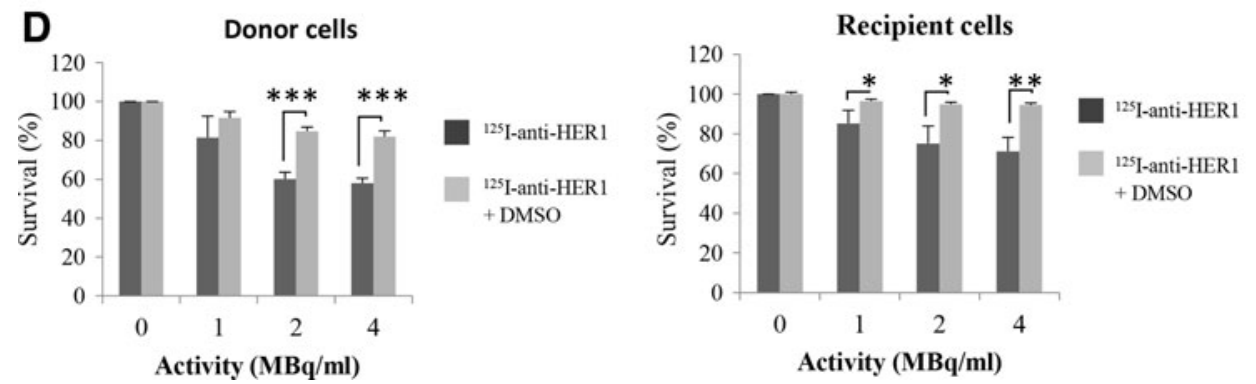

cholesterol-enriched domains called lipid rafts that are stabilized in some cells by caveolin (32). It has been shown that ASMase activated by hydroxyl radicals (56) translocates from the cytoplasm to the outer layer of the cell membrane, where it hydrolyzes sphingomyelin into hydrophobic ceramide and hydrophilic phosphorylcholine $(59,68)$. Ceramide production is accompanied by the coalescence of lipid raft microdomains into ceramide-enriched large platforms that can participate in the spatial reorganization of membrane receptors and in the activation of multiple signaling pathways. Several mechanisms leading to protein activation through membrane reorganization have been identified in response to $\operatorname{EBRT}(8,13,47)$.

Our results confirm that similar mechanisms might be involved in ${ }^{125} \mathrm{I}-\mathrm{mAb}$ efficacy after binding to the cell surface because we show that the localized energy deposition associated with ${ }^{125}$ I decays was accompanied by ASMase activation (Fig. 3D), formation of ceramide-enriched large platforms (Fig. 3A), and subsequent activation of signaling pathways (Fig. 5). ROS scavenging or disruption of lipid rafts, using MBCD or filipin, reduced not only the targeted cytotoxic effect of ${ }^{125} \mathrm{I}-\mathrm{mAbs}$ but also the nontargeted cytotoxic effect (Figs. 4 and 7). The use of filipin, a cholesteroldepleting agent, reduced the cytotoxic effect of $4 \mathrm{MBq} / \mathrm{ml}$ anti-CEA or anti-HER1 ${ }^{125} \mathrm{I}-\mathrm{mAbs}$ by about half in donor cells and by $75 \%-80 \%$ in recipient cells (Table 1 ), showing the involvement of lipid rafts in the cytotoxic effects of ${ }^{125} \mathrm{I}-$ mAbs. These results are supported by in vivo data showing that MBCD treatment removes the statistical significance of the therapeutic efficacy of ${ }^{125} \mathrm{I}$-anti-CEA mAb (Fig. 8).

A schematic representation of the mechanisms that might be involved in ${ }^{125} \mathrm{I}$-mAbs targeted cytotoxicity is proposed in Figure 10. Formation of ceramide-enriched large platforms is induced following ASMase activation mediated by ROS (56) originating from water radiolysis (presumably in a dosedependent manner) (Fig. 3D). ROS could also be generated 

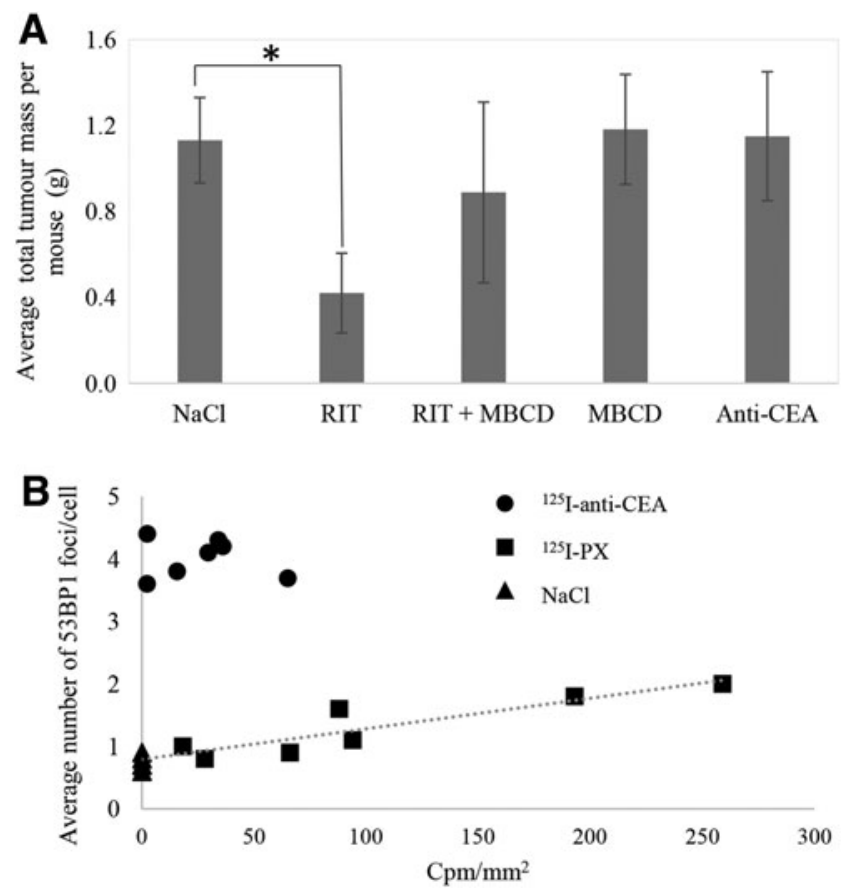

FIG. 8. In vivo therapeutic efficacy of ${ }^{125} \mathrm{I}-\mathrm{mAbs}$ with or without MBCD. (A) Mice bearing intraperitoneal A$431_{\text {CEA }}$ tumor xenografts were treated with $\mathrm{NaCl}$, unlabeled anti-CEA mAb (100 $\mu \mathrm{g} /$ injection at day 8 and 11), or with ${ }^{125}$ I-anti-CEA mAb (RIT) at day 8 and 11 postgraft, daily with MBCD from day 6 to 15 postgraft (MBCD), or with ${ }^{125}$ I-anti-CEA $\mathrm{mAb}$ (day 8 and 11 postgraft) and $\mathrm{MBCD}$ (daily from day 6 to 15 postgraft) (RIT+MBCD) $(n=8$ mice/ group). Tumors were collected at days 30 postgraft, and the total tumor mass was determined. (B) The level of 53BP1 was determined by immunofluorescence in cryocut slices of tumors of mice treated with $37 \mathrm{MBq}$ of ${ }^{125} \mathrm{I}$-anti-CEA mAbs, ${ }^{125} \mathrm{I}$-PX mAbs (RIT), or with $\mathrm{NaCl}$. The level was determined in 100 cells of a selected area and was correlated with the level of radioactivity $\left(\mathrm{cpm} / \mathrm{mm}^{2}\right)$ of the same area. Between 6 and 7 areas of tumors in different mice were selected. In A, results are the mean \pm SD of eight values. ${ }^{*} p<0.05$ compared to mice treated with $\mathrm{NaCl}$. 53BP1, p53binding protein 1 ; MBCD, methyl- $\beta$-cyclodextrin.

following lipid raft-mediated activation of $\mathrm{NAD}(\mathrm{P}) \mathrm{H}$ oxidase $(36,67)$. ROS contribute to "chronic" oxidative stress and the subsequent DNA damage, including the formation of micronuclei in nontargeted cells $(3,44)$. This is in agreement with our previous finding that the abundance of micronuclei in cells exposed to ${ }^{125} \mathrm{I}-\mathrm{mAbs}$ was not correlated with the mean absorbed dose to the nucleus $(48,50)$. The involvement of oxidative stress in EBRT-induced nontargeted effects has been extensively reviewed by Havaki et al. (20). Irradiated cells produce ROS and RNS through radiolysis and cytokines. ROS and RNS are then directly transmitted to bystander cells through gap junctions or through release in the extracellular medium (20). In bystander cells, different signaling pathways participate in the upregulation of genes encoding cytokines, cyclooxygenase-2 (COX2), and inducible nitric oxide synthase (iNOS) that generate intracellular ROS and RNS (20). However, the involvement of such mechanisms following low dose rate and protracted exposure (as in RIT) needs to be confirmed. The present study focused on the mechanisms involved in irradiated donor cells, and we assume that the main source of oxidative stress was associated with radiation and hydroxyl radical formation. Elucidation of the precise mechanisms involved in recipient cells would require further work.

It is noteworthy that ${ }^{125}$ I decays must occur at the surface of targeted cells to initiate the nontargeted response. Indeed, our data show that low LET radiation (including electrons and soft X-rays) emitted by the irrelevant PX ${ }^{125} \mathrm{I}-\mathrm{mAb}$, which does not interact with cells, did not produce a significant nontargeted response. This suggests that nontargeted effects are induced mainly by high LET Auger electrons (of very low range) generated at the cell surface when ${ }^{125} \mathrm{I}-\mathrm{mAbs}$ bind to CEA or HER1 receptors.

The relative contribution of the various signaling pathways activated by cell membrane reorganization following lipid raft formation is complex and remains to be elucidated. We show that the mitogen-activated protein kinases (MAPKs), ERK1/2, P38, JNK, and AKT, and their downstream proteins, are activated during exposure to ${ }^{125} \mathrm{I}$-mAbs. The role of these kinases in our model is still unclear because AKT and ERK1/ 2 promote cell survival, while ceramide, p38, JNK, and its downstream target c-JUN participate in cell death. However, the use of p38 or (to a lesser extent) of JNK inhibitors was accompanied by a stronger effect on clonogenic survival (increase) than the use of PI3K or MEK inhibitors, suggesting the cell death mechanisms predominate (Fig. 6). We also found that S1P, the hydrolysis product of sphingosine that is generated from ceramide by ceramidase (Figs. 3E and 10), was upregulated following exposure to anti-CEA ${ }^{125} \mathrm{I}-\mathrm{mAb}$. Contrary to ceramide, S1P inhibits apoptosis and stimulates cell proliferation through activation of the AKT and e-NOS pathways [for review, Oskouian and Saba (45)]. Paxillin also was activated by incubation with anti-CEA ${ }^{125} \mathrm{I}-\mathrm{mAb}$ (Fig. 5). Paxillin can be phosphorylated by focal adhesion kinase (FAK) or PYK-2, and phosphorylated paxillin serves as a scaffold protein to facilitate the functional integration of focal adhesion proteins. Paxillin is phosphorylated during EBRT as a downstream protein target (together with AKT and ERK1/2) of FAK (21).

Moreover, our data suggest a possible role of ion channels located in lipid rafts, such as $\mathrm{Ca}^{2+}$ channels. The role of $\mathrm{Ca}^{2+}$ in EBRT-associated nontargeted effects has clearly been demonstrated (38). The influx of extracellular $\mathrm{Ca}^{2+}$ can be regulated by ceramide (11), but also by PLC- $\gamma$ that is activated upon exposure to anti-CEA ${ }^{125} \mathrm{I}-\mathrm{mAb}$ (Fig. 5A). During EBRT, PLC$\gamma$ localized at the plasma membrane produces inositol triphosphate (IP3) that consequently induces $\mathrm{Ca}^{2+}$ release from the endoplasmic reticulum through IP3 receptors (60). Such an increase in $\mathrm{Ca}^{2+}$ cytoplasmic concentration could also contribute to the phosphorylation of PYK-2 observed in cells exposed to anti-CEA ${ }^{125} \mathrm{I}-\mathrm{mAb}$ (Fig. 5A) (34). PYK-2, a member of the FAK family, is involved in cell proliferation and phosphorylates paxillin. However, incubation of donor cells with EGTA, a chelator of extracellular calcium, was not accompanied by modifications in clonogenic survival. In a previous study, Lyng et al. have used EGTA in combination with verapamil and nifedipine to block also voltage-dependent calcium channels (38) to investigate the role of $\mathrm{Ca}^{2+}$ ions. Such an approach merits further investigation in our models also.

Finally, we investigated in A-431 $1_{\text {CEA }}$ tumor xenografts from mice injected with anti-CEA ${ }^{125} \mathrm{I}-\mathrm{mAb}$ whether the induction of DNA DSBs could be correlated with the 
A

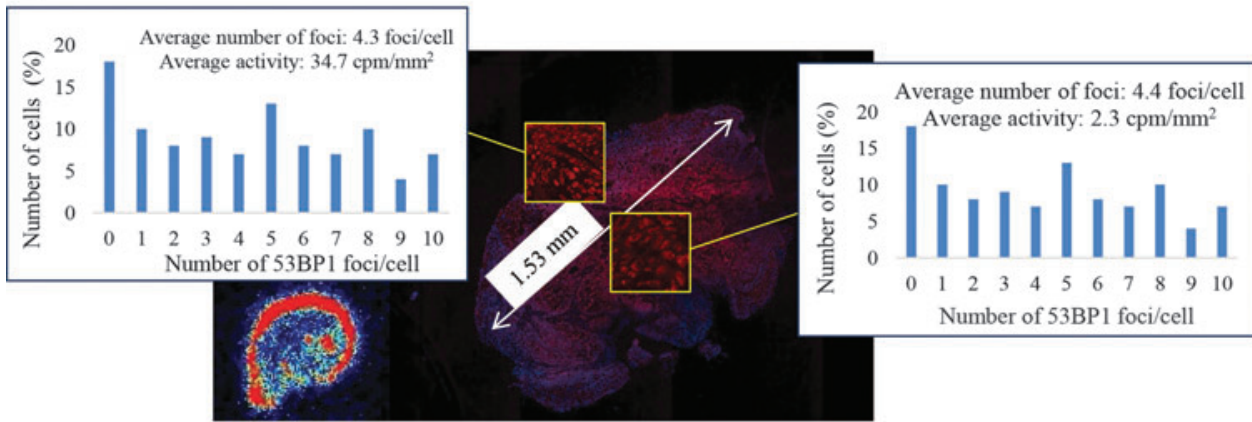

B
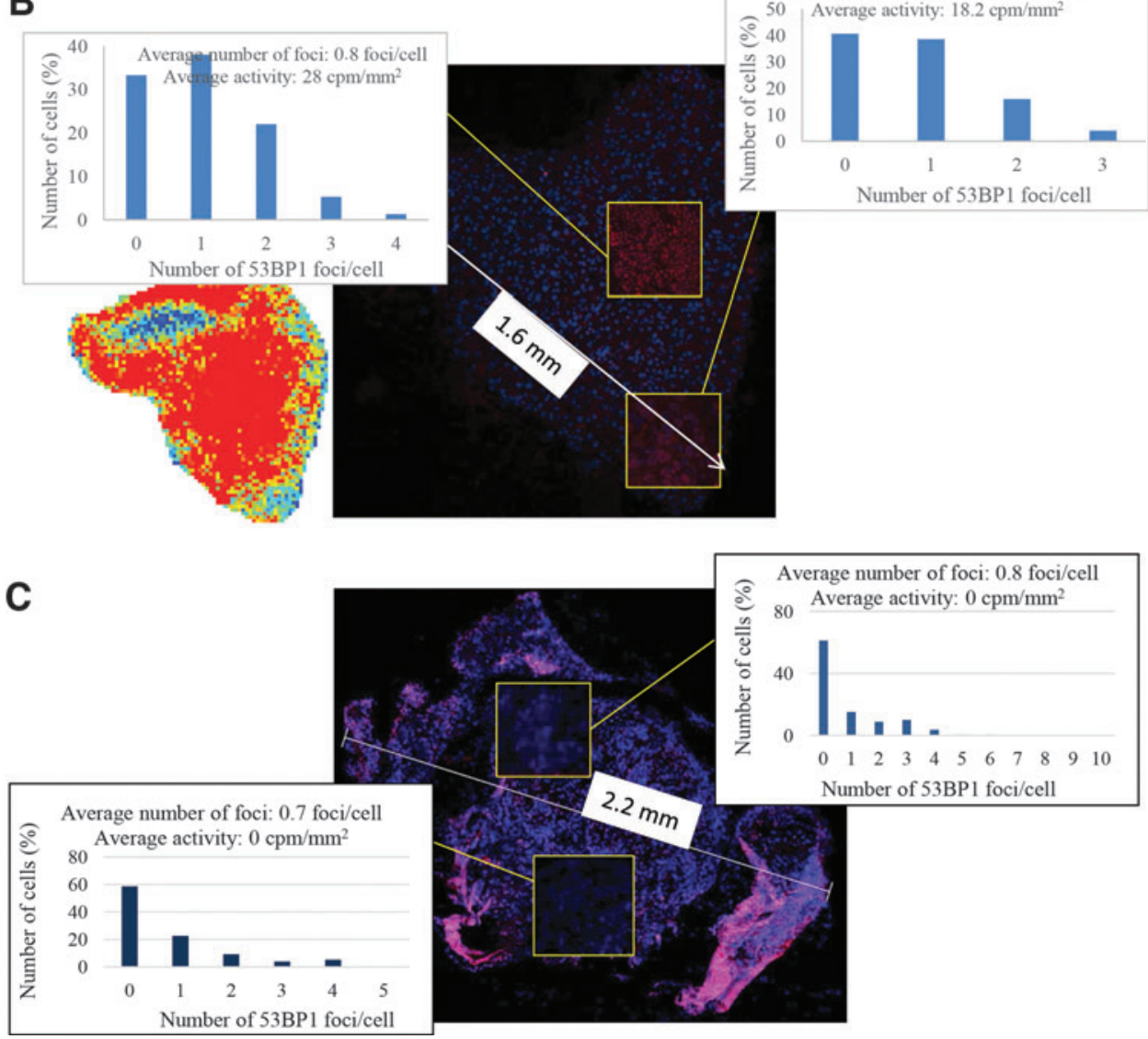

FIG. 9. Radioactivity distribution and 53BP1 induction do not overlap in

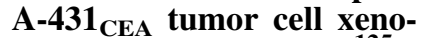
grafts treated with ${ }^{125} \mathrm{I}$ anti-CEA mAbs. Digital autoradiography (inset on the bottom left side of each panel) and immunohistochemical detection of 53BP1 in tumor sections from mice xenografted intraperitoneally with A-431 $1_{\text {CEA }}$ cells and treated $24 \mathrm{~h}$ before tissue collection with a single intraperitoneal injection of $37 \mathrm{MBq}$ of (A) ${ }^{125}$ I-anti-CEA mAb, (B) ${ }^{125}$ I-anti-PX mAb, or (C) injected with $\mathrm{NaCl}$. The distribution of 53BP1 foci was determined in 100 cells of relevant areas of tumors. Between 6 and 7 areas of tumors in different mice were selected. To see this illustration in color, the reader is referred to the web version of this article at www .liebertpub.com/ars distribution of radioactivity. We observed that radioactivity was mainly localized at the periphery of tumors, whereas DNA DSBs were homogenously distributed throughout the tumor (Figs. 8B and 9A).

A lower DSB induction was detected after ${ }^{125} \mathrm{I}-\mathrm{PX} \mathrm{mAb}$ treatment, despite the higher nonspecific uptake of radioactivity, for some of the tumors, compared to anti-CEA ${ }^{125} \mathrm{I}-$ $m A b$. These data indicate that the DSBs observed after treatment with anti-CEA ${ }^{125} \mathrm{I}-\mathrm{mAb}$ were not due to nonspecific irradiation. Indeed, we analyzed ${ }^{125} \mathrm{I}-\mathrm{PX}$ mAb-treated tumors showing high tumor uptake to be able to exclude the possibility that DNA DSBs measured in the center of the tumor were caused by nonspecific irradiation of ${ }^{125} \mathrm{I}$ (mainly soft X-rays and electrons) from the tumor periphery to the center. We could also exclude any contribution from blood circulating ${ }^{125} \mathrm{I}-\mathrm{mAbs}$ in mouse. As the major contribution to the absorbed dose from ${ }^{125} \mathrm{I}$ is due to Auger electrons, radioactivity distribution may be considered to be indicative of the distribution of the absorbed dose. The reason for the observed higher uptake in some areas of tumor of ${ }^{125} \mathrm{I}-\mathrm{PX}$ mAb-treated mice compared with those treated with ${ }^{125} \mathrm{I}$ anti-CEA mAb (especially the center) is unclear.

It could be that while the nonspecific antibody is able to freely diffuse to the center of the tumor, the CEA binding antibody binds to receptors, and the first of those encountered would be in the periphery. Unless these receptors in the periphery become saturated, substantial penetration of further unbound antibody molecules would be prevented. Notwithstanding this effect, whatever the distribution of radioactivity, we have previously shown that ${ }^{125} \mathrm{I}-\mathrm{PX} \mathrm{mAb}$ does not have a therapeutic effect in vivo (53). Accordingly, our results indicate that DNA DSB formation did not correlate with 
FIG. 10. Schematic of the mechanisms involved in RIT using ${ }^{125}$ I-mAbs. ${ }^{125} \mathrm{I}$ mAbs targeting the cell membrane deliver high and localized energy at the cell surface. ASMase is activated by ROS produced by radiation energy deposition. ASMase catalyzes sphingomyelin hydrolysis to ceramide and phosphorylcholine. Ceramide modifies the cell membrane biophysical properties and participates in the coalescence of sphingolipid- and cholesterol-enriched domains (called lipid rafts) into large ceramide-enriched platforms, leading to cell membrane receptor reorganization and activation of the ERK1/2, AKT, p38/JNK signaling pathways, and their downstream targets. Activation of phospholipase $\mathrm{C}-\gamma$ and of $\mathrm{Ca}^{2+}$-dependent PYK-2 and paxillin is also observed. Lipid raft-dependent radiation-induced nontargeted effects, including cytotoxicity and $\gamma \mathrm{H} 2 \mathrm{AX}$ formation, are observed in neighboring cells, whatever the localization of ${ }^{125}$ I (cell surface or nucleus) and independently of the decay number $\left(1047 \mathrm{~Bq} \cdot \mathrm{s}\right.$ for ${ }^{125} \mathrm{I}$ $\mathrm{mAbs}$ and $441 \mathrm{~Bq} \cdot \mathrm{s}$ for ${ }^{125} \mathrm{I}-$ UdR). Nontargeted effects are strongly reduced by filipin or MBCD. ${ }^{125}$ I-UdR, 5-[(125)I] iodo-2'-deoxyuridine; PLC- $\gamma$, phospholipase C- $\gamma$; PYK-2, proline-rich tyrosine kinase 2 ; ROS, reactive oxygen species. To see this illustration in color, the reader is referred to the web version of this article at www .liebertpub.com/ars

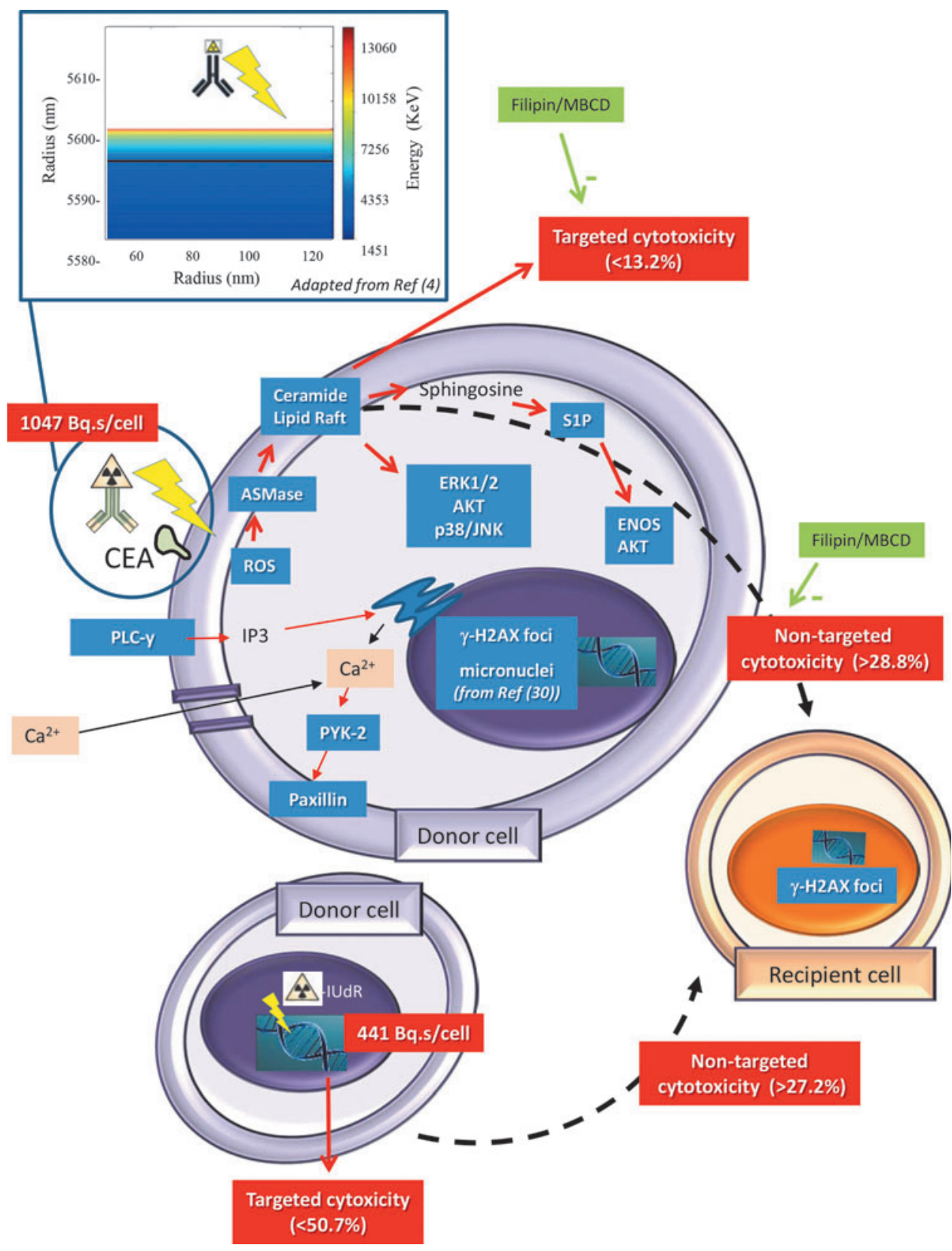

the absorbed dose and that DNA damage occurred to a similar extent both within and beyond the range of the ${ }^{125} \mathrm{I}$ Auger electrons. In a similar approach using ${ }^{212} \mathrm{~Pb}-\mathrm{mAb}$ for treating A-431 $1_{\text {CEA }}$ tumor xenografts, we also observed that distribution of DNA damage and induction of abnormal mitosis do not correlate with tumor absorbed dose, a phenomenon not observed with ${ }^{212} \mathrm{~Pb}-\mathrm{PX}$ nonspecific mAb (data not shown). These data support the involvement, in vivo, of nontargeted effects during ${ }^{125} \mathrm{I}-\mathrm{mAb}$ RIT, but this needs to be confirmed in further experiments.

One of the issues raised by our study is related to radiation protection since nonirradiated tissues can show DNA damage and subsequent possible cell death or cell transformation. This may have implications for nuclear medicine where about one atom in two $\left({ }^{99 \mathrm{~m}} \mathrm{Tc},{ }^{123} \mathrm{I},{ }^{125} \mathrm{I},{ }^{201} \mathrm{Tl},{ }^{51} \mathrm{Cr},{ }^{67} \mathrm{Ga}\right.$, etc.) emits Auger electrons associated with other particles. It was generally considered that Auger binding DNA, or localized in the cell nucleus, produces high LET radiation. However, there is no guidance on how to calculate the equivalent dose for these radionuclides. It has been proposed by the American Association of Physicists in Medicine that the component of dose from the Auger electrons for radionuclides bound to DNA should be given a preliminary radiation weighting factor of 10 for deterministic effects and 20 for stochastic effects for nuclear localization while ICRP has recommended considering each situation (isotope and localization) separately $(23,24)$. The dose equivalent calculated with these weighting factors must be modulated by experimentally determined subcellular distributions of the Auger electron emitters. Our study indicates that the nontargeted effect of Auger electron emitters bound to the cell surface has to be considered.

In conclusion, we have shown that Auger electron emitters, such as ${ }^{125} \mathrm{I}$, conjugated to mAbs directed against the cancer cell surface can be cytotoxic by a cell oxidative, stress- 
mediated nontargeted mechanism involving lipid rafts. This nontargeted effect is comparable to that induced by ${ }^{125} \mathrm{I}-\mathrm{UdR}$ concentrated in the nucleus of tumor cells. Compared with ${ }^{125} \mathrm{I}$-UdR, lower targeted cytotoxicity is expected when using ${ }^{125} \mathrm{I}-\mathrm{mAbs}$, but the induction of nontargeted effects could compensate for the inferior efficacy of non-nuclear targeting. Moreover, ${ }^{125} \mathrm{I}-\mathrm{mAbs}$ should also be less toxic toward proliferating normal tissue, thus allowing an increase in the injected activities.

These findings are particularly relevant for targeted therapy in which vectors cannot gain access to every tumor cell. Their extrapolation to targeted alpha radiotherapy, now routinely used in clinical radionuclide therapy, should be evaluated.

\section{Materials and Methods}

\section{Cell lines}

A-431 $1_{\text {CEA }}$ and SK-OV-3 ${ }_{\text {CEA }}$ cells were obtained by transfecting A-431 vulvar squamous and SKOV-3 ovarian carcinoma cells (from ATCC, Molsheim, France), respectively, using vectors encoding the CEA. $p 53^{+/+}$HCT116 colon adenocarcinoma cells were obtained from ATCC. The $p 53^{-/-}$HCT116 cell line was a kind gift from Professor Bert Vogelstein. HCT116 cells were grown in RPMI 1640 medium supplemented with $10 \%$ (v/v) fetal calf serum (FCS), $2 \mathrm{~m} M$ L-glutamine, and antibiotics $(0.1 \mathrm{U} / \mathrm{ml}$ penicillin and $100 \mu \mathrm{g} / \mathrm{ml}$ streptomycin) at $37^{\circ} \mathrm{C}$ in a humidified atmosphere with $5 \% \mathrm{CO}_{2}$. A-431 $\mathrm{CEA}$ and $\mathrm{SKOV}-3_{\mathrm{CEA}}$ cells were grown as described (50). All cell culture reagents were from Life Technologies (Thermo Fisher Scientific, Waltham, MA).

\section{Radiolabeled vectors for cell targeting}

To target the cytoplasm, ${ }^{125}$ I was coupled to the internalizing mouse m225 mAb. ${ }^{125}$ I-labeled $\mathrm{m} 225 \mathrm{mAb}$ is internalized within the cytoplasm after binding to its receptor (HER1). For cell surface localization, ${ }^{125}$ I was coupled to the noninternalizing mouse IgG1k mAb 35A7. For the CEA Gold 2 epitope (50), 35A7 is specific. The nonspecific PX antibody was used as a control (irrelevant antibody). PX is an IgG1 mAb purified from mouse myeloma P3-X63 cells (30). The three mAbs were obtained from mouse hybridoma ascites fluids by ammonium sulfate precipitation followed by ion exchange chromatography on DE52 cellulose (Whatman, Balston, United Kingdom).

Antibody radiolabeling was performed according to the IODO-GEN (1,3,4,6-tetrachloro-3 $\alpha, 6 \alpha$-diphenylglycoluryl) (Sigma-Aldrich, St. Louis, MO) method (50). ${ }^{125} \mathrm{I}-\mathrm{mAb}-$ specific activity was $370 \mathrm{MBq} / \mathrm{mg}$ of protein, and immunoreactivity was $60 \%-95 \%$. All experiments used ${ }^{125} \mathrm{I}-\mathrm{mAb}$ activities $\leq 4 \mathrm{MBq} / \mathrm{ml} .{ }^{125} \mathrm{I}$ was targeted to the nucleus using the thymidine base analogue ${ }^{125} \mathrm{I}-\mathrm{UdR}$ at a specific activity of 81.4 TBq/mmol. ${ }^{125} \mathrm{I}-\mathrm{UdR}$ was purchased from PerkinElmer (Waltham, MA).

\section{$R I T$, medium transfer, and clonogenic survival of irradiated and nonirradiated cells}

p53 $3^{+/+}$or $p 53^{-/-}$HCT 116, SK-OV- $3_{\mathrm{CEA}}$, and A-431 $\mathrm{CEA}$ cells were cultured in 6-cm Petri dishes (100-500 cells/dish) with $3 \mathrm{ml}$ of medium. The following day, cells were incubated with ${ }^{125} \mathrm{I}-\mathrm{mAbs}$ at activities $\leq 4 \mathrm{MBq} / \mathrm{ml}$ for $48 \mathrm{~h}$ (donor cells). For targeting of the nucleus, due to the higher toxicity of ${ }^{125} \mathrm{I}-\mathrm{UdR}$, between 100 and $1200 \mathrm{p53}^{+/+}$HCT116 cells were seeded in 6-cm Petri dishes containing $3 \mathrm{ml}$ of medium and exposed, the following day, to ${ }^{125} \mathrm{I}-\mathrm{UdR}$ activities of $\leq 20$ $\mathrm{kBq} / \mathrm{ml}$ for $48 \mathrm{~h}$. Culture medium was then removed, and cells were washed twice with $4 \mathrm{ml}$ phosphate buffered saline (PBS). For clonogenic assays, performed as described in (50), fresh medium $(3 \mathrm{ml})$ was added and donor cells were cultured for 12 days. For investigating the nontargeted response, fresh medium $(3 \mathrm{ml})$ was added to donor cells for $2 \mathrm{~h}$ and then transferred to dishes in which cells had been seeded the day before (recipient cells: $100-500$ cells $/ 6 \mathrm{~cm}$ dish). The transferred medium was checked for radioactivity (values were generally very low, comprising between $0.08 \%$ and $0.10 \%$ of the activity incubated with donor cells). Donor and recipient cells were then grown for 12 days and colonies stained with crystal violet $(2.5 \mathrm{~g} / 1$ in $45: 530 \%$ [v/v] methanol/paraformaldehyde). Colonies containing 50 or more cells were scored, and the surviving fraction was calculated. The toxicity of unlabeled mAbs was assessed using the same experimental conditions.

\section{Drug treatment}

To determine the role of $\mathrm{mAb}$ internalization in the bystander response, $p 53^{+/+}$HCT116 cells were exposed for 2 days to ${ }^{125} \mathrm{I}-\mathrm{mAbs}$ of activity concentration $\leq 4 \mathrm{MBq} / \mathrm{ml}$ in the presence of $0.02 \%(\mathrm{w} / \mathrm{v})$ sodium azide, a drug that blocks $\mathrm{mAb}$ transport into the cytoplasm.

The role of cell membrane lipid raft formation in ${ }^{125} \mathrm{I}-$ $\mathrm{mAb}$-induced bystander effects was investigated by coincubating $p 53^{+/+}$HCT116 donor cells with ${ }^{125} \mathrm{I}-\mathrm{mAbs}$ and $4 \mathrm{~m} M$ MBCD (Sigma-Aldrich) for $6 \mathrm{~h}$ or with $2.5 \mu \mathrm{g} / \mathrm{ml} \mathrm{fi-}$ lipin (Sigma-Aldrich) overnight.

The potential role of oxidative stress in the induction of bystander effects was assessed by coincubating $p 53^{+/+}$ HCT116 donor cells with ${ }^{125} \mathrm{I}-\mathrm{mAbs}$ and $50 \mu M$ NAC (Sigma-Aldrich) (for 2 days) or $0.5 \%$ DMSO (SigmaAldrich) (overnight)

\section{Immunofluorescence analysis of $m A b$ localization, lipid rafts, and $\gamma \mathrm{H} 2 \mathrm{AX}$ foci}

For immunofluorescence studies, $p 53^{+/+}$HCT116 cells were plated on $12-\mathrm{mm}$ glass coverslips in culture dishes. They were fixed in $3.7 \%(\mathrm{v} / \mathrm{v})$ formaldehyde and then permeabilized in $0.1 \%$ (v/v) Triton X-100 for 15 min followed by incubation with $1 \%(\mathrm{v} / \mathrm{v})$ PBS/bovine serum albumin (BSA) for $1 \mathrm{~h}$. To confirm the mAb localization, an Alexa-488-conjugated anti-mouse secondary $\mathrm{mAb}$ was used at a dilution of 1:200 (Invitrogen, Saint Aubin, France). F-actin was stained with conjugated phalloidin (1:5000; Sigma-Aldrich), and nuclei with $0.1 \mu \mathrm{g} / \mathrm{ml}$ Hoechst (Sigma-Aldrich). To visualize lipid rafts, $p 53^{+/+}$ HCT116 cells were incubated with Alexa-488-conjugated cholera toxin (Sigma-Aldrich) at a dilution of 1:1000. $\gamma \mathrm{H} 2 \mathrm{AX}$ foci were quantified in $p 53^{+/+}$HCT116 cells after exposure to ${ }^{125} \mathrm{I}$-mAbs for 2 days according to previously described methodology (48). For immunofluorescent colocalization of ceramide and apoptosis marker, cells were incubated with anticeramide 15B4 antibody at dilution 1:10 (Alexis Biochemicals, Heidelberg, Germany) for $1 \mathrm{~h}$ at $37^{\circ} \mathrm{C}$ followed by three PBS washing steps and incubation with PE-conjugated goat antimouse IgM at a dilution of 1:200 (Jackson Immuno Research, Baltimore, PA) and annexin V conjugated with FITC dilution 
1:100 (Beckman Coulter, Marseille, France). Coverslips were then mounted in Mowiol $^{\circledR}$ (Sigma-Aldrich), and images recorded using a $63 \times$ or $100 \times$ NA objective and a Leica (Leica Microsystems, Wetzlar, Germany) inverted microscope.

\section{Proteome array, subcellular fractionation, and Western blotting}

The Human Phospho-Kinase array (Proteome Profiler Array; R\&D Systems, Minneapolis, MN) was used to detect the relative phosphorylation levels of 46 kinases in $p 53^{+/+}$ HCT116 cellular extracts according to the manufacturer's protocol. To confirm the localization of the targeting mAbs, a subcellular protein fractionation kit (Thermo Scientific) was used according to the manufacturer's protocol. For Western blotting, membrane and cytosolic protein fractions and total lysates ( $40 \mu \mathrm{g}$ of each) from $p 53^{+/+}$HCT116 cells and A- $431_{\text {CEA }}$ were separated by sodium dodecyl sulfate polyacrylamide gel electrophoresis and electrotransferred to polyvinylidene difluoride membranes (Amersham Pharmacia Biotech, Uppsala, Sweden). Membranes were incubated with the 35A7 (anti-CEA), m225 (anti-EGFR), sodium/potassium ATPase (1:1000; Abcam, Cambridge, United Kingdom), and anti-tubulin (1:10,000; Abcam) primary antibodies that were then detected with horseradish peroxidase-conjugated goat anti-mouse or anti-rabbit (Sigma-Aldrich) secondary antibodies. p-ERK, p-AKT, and p-p38 were detected by primary anti-p-ERK, anti-p-AKT, and anti-p-p38 antibodies (Cell Signaling Technology, Danvers, MA) followed by incubation with horseradish peroxidase-conjugated goat anti-mouse or anti-rabbit (Sigma-Aldrich) secondary antibodies. Proteins were detected by enhanced chemoluminescence (ECL) using the ECL detection system from Amersham Biosciences (Saclay, France).

\section{Ceramide measurement by flow cytometric analysis}

Ceramide levels present in the cell membrane of $p 53^{+/+}$ HCT116 cells were assessed by flow cytometry. Cells were treated with unlabeled mAbs $(20 \mu \mathrm{g} / \mathrm{ml})$ or ${ }^{125} \mathrm{I}-\mathrm{mAbs}$ $(4 \mathrm{MBq} / \mathrm{ml})$ at $37^{\circ} \mathrm{C}$ for $1 \mathrm{~h}$. After three washes, cells were fixed in $3.7 \%(\mathrm{v} / \mathrm{v})$ paraformaldehyde for $15 \mathrm{~min}$. Then, cells were washed three times in PBS buffer and incubated with the anti-ceramide $15 \mathrm{~B} 4 \mathrm{mAb}$ at a dilution of 1:50 (Alexis Biochemicals) at $37^{\circ} \mathrm{C}$ for $1 \mathrm{~h}$. After three washes in PBS$2 \%$ FCS, cells were incubated with PE-conjugated goat antimouse IgM at a dilution of 1:100 (Jackson ImmunoResearch) in the dark for $1 \mathrm{~h}$. Cells were then washed three times and suspended in PBS for analysis using a Muse flow cytometer (Merck Millipore, Fullerton, CA). The $y$ axis corresponds to the total number of analyzed cells (arbitrary units), while the $x$ axis represents the fluorescence signal intensity (PEconjugated goat $\mathrm{mAb}$ anti-ceramide $15 \mathrm{~B} 4 \mathrm{mAb}$ ). The numbers provided in the red boxes correspond to the proportion of ceramide-positive cells within the total population of cells compared with the nontreated control.

\section{Inhibitors of MAPK pathways and chelation of extracellular $\mathrm{Ca}^{2+}$}

To confirm the involvement of MAPK proteins, including AKT, ERK1/2, p38, and JNK on final survival outcome, HCT116 donor cells were incubated for $48 \mathrm{~h}$ with ${ }^{125} \mathrm{I}$-anti-
CEA $\mathrm{mAb}$ in the presence of $1 \mu M$ of PI3K inhibitor (ZSTK474), and indirectly of downstream AKT signaling pathway, $1 \mu M$ of MEK1/2 inhibitor (U0126), and indirectly of downstream ERK1/2 signaling pathway, $10 \mu M$ of SP600125 (JNK inhibitor), $10 \mu M$ of SB203580 (p38 inhibitor), or $5 \mathrm{mM}$ EGTA (to chelate extracellular $\mathrm{Ca}^{2+}$ ions). Donor cells were preincubated with inhibitors $1 \mathrm{~h}$ before addition of ${ }^{125} \mathrm{I}$-mAbs. After $48 \mathrm{~h}$, medium was removed and standard medium transfer protocol was followed as previously described. Clonogenic survival of both donor and recipient cells was measured. The efficacy of ZSTK474 and of U0126 in inhibiting AKT and ERK1/2 was confirmed by Western blotting (Supplementary Fig. S3B, right panel).

\section{Measurement of ASMase activity}

ASMase activity in whole cell lysates of $p 53^{+/+}$HCT116 cells exposed to ${ }^{125} \mathrm{I}-\mathrm{mAbs}(0-4 \mathrm{MBq} / \mathrm{ml})$ for 2 days was measured using the Amplex Red Sphingomyelinase Assay Kit (Molecular Probes, Saint Aubin, France). The ASMase activity of experimental samples and positive control was calculated as a percentage of the ASMase activity of the negative control.

\section{Measurement of S1P concentration}

The level of S1P was determined in $p 53^{+/+}$HCT116 cells exposed to ${ }^{125} \mathrm{I}-\mathrm{mAbs}(4 \mathrm{MBq} / \mathrm{ml})$ for 2 days using the Sphingosine 1 Phosphate Assay Kit according to the manufacturer's protocol (Echelon Biosciences, Salt Lake City, UT).

\section{Animal model}

Swiss nude mice (7-week-old females) from Charles River were acclimated for 1 week before experimental use. They were housed at $22^{\circ} \mathrm{C}$ and $55 \%$ humidity with a light-dark cycle of $12 \mathrm{~h}$. Food and water were available ad libitum. Body weight was determined weekly, and the mice were clinically examined throughout the study. All animal experiments were performed in compliance with the guidelines of the French government and the INSERM standards for experimental animal studies (agreement B34-172-27).

\section{In vivo experiments}

Swiss nude mice (7-week-old females) from Charles River were xenografted intraperitoneally (i.p.) with $1.5 \times 10^{6} \mathrm{~A}-431_{\mathrm{CEA}}$ cells suspended in $0.3 \mathrm{ml}$ PBS. The A$431_{\mathrm{CEA}}$ cell line was chosen for in vivo ${ }^{125} \mathrm{I}$ experiments because it expresses high levels of CEA receptors (compared with HCT116 cells), which enables treatment with a tumoricidal dose.

RIT experiments with or without MBCD. For these experiments, 32 mice were divided in four groups $(n=8 /$ each) that were treated as follows: (i) two i.p. injections of $\mathrm{NaCl}$ at day 8 and 11 postgraft, (ii) two i.p. injections of anti-CEA $\mathrm{mAb}(100 \mu \mathrm{g})$ at day 8 and 11, (iii) two i.p. injections of $37 \mathrm{MBq}$ of ${ }^{125}$ I-anti-CEA mAb at day 8 and 11, (iv) daily i.p. injections of $300 \mathrm{mg} / \mathrm{kg} \mathrm{MBCD}$ from day 6 to 15 postgraft, and (v) daily i.p. injections of MBCD from day 6 to 15 and two injections of $37 \mathrm{MBq}$ of ${ }^{125} \mathrm{I}$-anti-CEA mAb at day 8 and 11 postgraft. At day 30 postgraft, mice were sacrificed, tumors collected, and the total tumor mass was determined. 
For this purpose, length, width, and depth of each tumor nodule was measured and used for calculating the nodule volume and a density of $1.05 \mathrm{~g} / \mathrm{cm}^{3}$ was used to determine each nodule mass. The average total tumor mass for each mouse was calculated by summing up the mass value of each nodule.

Digital autoradiography and immunohistochemical detection of 53BP1. Ten days postgraft, eight mice were injected i.p. with $37 \mathrm{MBq}$ of ${ }^{125} \mathrm{I}-\mathrm{PX}$ or of ${ }^{125} \mathrm{I}$-anti-CEA mAbs. Four and $24 \mathrm{~h}$ later, mice were anesthetized, bled, and dissected. Tumors were collected and frozen after inclusion in optimal cutting temperature embedding matrix. Two consecutive $10 \mu \mathrm{m}$-thick frozen sections were analyzed by digital autoradiography (DAR) or by immunohistochemical analysis. DAR acquisition was performed using a Beta Imager 2000 instrument (Biospace, Paris, France) over $24 \mathrm{~h}$ and analyzed using M3vision software to determine the radioactivity distribution. Immunofluorescence analysis of 53BP1 expression was performed to assess DNA DSB formation. Frozen sections were rehydrated in PBS for $10 \mathrm{~min}$, fixed in $3.7 \%(\mathrm{v} / \mathrm{v})$ formaldehyde, and then permeabilized in $0.5 \%(\mathrm{v} / \mathrm{v})$ Triton X-100 for $15 \mathrm{~min}$ followed by incubation with $10 \%(\mathrm{v} / \mathrm{v})$ PBS/BSA for $1 \mathrm{~h}$. Sections were incubated at $37^{\circ} \mathrm{C}$ with an anti-53BP1 mAb (1:400) for $1 \mathrm{~h}$ followed by incubation with an Alexa-594-conjugated anti-rabbit secondary antibody (1:500; Invitrogen). Nuclei were stained with $0.1 \mu \mathrm{g} / \mathrm{ml}$ Hoechst. The distribution of 53BP1 foci was determined in 100 cells in two relevant areas of representative tumors. All animal experiments were performed in compliance with the guidelines of the French government and the INSERM standards for experimental animal studies (agreement B34172-27). They were approved by the local ethic committee of "Institut de Recherche en Cancérologie de Montpellier", (IRCM/INSERM) and by the Ethic Committee of Languedoc Roussillon (CEEA LR France No. 36) for animal experiments under the number 1056.

\section{Statistical analysis}

All in vitro data were obtained from four independent experiments in triplicate. Data were described using mean and standard deviation. Analysis of variance was used for multigroup comparisons (significance level set at $\alpha=0.05$ ). Pairwise comparisons were performed using the Student's $t$ test, and to control for multiple testing, the significance threshold was set at 0.013 in these comparisons.

Data were analyzed using Stata software, version 13 (StataCorp, College Station, TX).

\section{Acknowledgments}

This work was supported by Action Nu1.1 of Plan Cancer 2009-2013 (ASC 13038FSA), by the French National Research Agency under the program "Investissements d'avenir' Grant agreement LabEx MAbImprove: ANR-10LABX-53, Grant INCa-DGOS-Inserm 6045, and the People Programme (Marie Curie Actions) of the European Union's Seventh Framework Programme (FP7/2007-2013) under REA grant agreement No. 608765 and Marie Curie WHRI Academy COFUND programme.

\section{Author Disclosure Statement}

No competing financial interests exist.

\section{References}

1. Anthony LB, et al. Indium-111-pentetreotide prolongs survival in gastroenteropancreatic malignancies. Semin Nucl Med 32: 123-132, 2002.

2. Azzam EI, de Toledo SM, and Little JB. Oxidative metabolism, gap junctions and the ionizing radiation-induced bystander effect. Oncogene 22: 7050-7057, 2003.

3. Azzam EI, et al. Oxidative metabolism modulates signal transduction and micronucleus formation in bystander cells from alpha-particle-irradiated normal human fibroblast cultures. Cancer Res 62: 5436-5442, 2002.

4. Belyakov OV, et al. Delayed lethality, apoptosis and micronucleus formation in human fibroblasts irradiated with X-rays or alpha-particles. Int J Radiat Biol 75: 985-993, 1999.

5. Bishayee A, Rao DV, and Howell RW. Evidence for pronounced bystander effects caused by nonuniform distributions of radioactivity using a novel three-dimensional tissue culture model. Radiat Res 152: 88-97, 1999.

6. Boyd M, et al. Radiation-induced biologic bystander effect elicited in vitro by targeted radiopharmaceuticals labeled with alpha-, beta-, and auger electron-emitting radionuclides. J Nucl Med 47: 1007-1015, 2006.

7. Bradley EW, Chan PC, and Adelstein SJ. The radiotoxicity of iodine-125 in mammalian cells. I. Effects on the survival curve of radioiodine incorporated into DNA. Radiat Res 64: 555-563, 1975.

8. Chalfant CE, et al. Long chain ceramides activate protein phosphatase-1 and protein phosphatase-2A. Activation is stereospecific and regulated by phosphatidic acid. $J$ Biol Chem 274: 20313-20317, 1999.

9. Chen $\mathrm{P}$, et al. Antitumor effects and normal tissue toxicity of ${ }^{111}$ In-labeled epidermal growth factor administered to athymic mice bearing epidermal growth factor receptorpositive human breast cancer xenografts. J Nucl Med 44: 1469-1478, 2003.

10. Chouin N, et al. Evidence of extranuclear cell sensitivity to alpha-particle radiation using a microdosimetric model. II. Application of the microdosimetric model to experimental results. Radiat Res 171: 664-673, 2009.

11. Church LD, et al. TNFR1-induced sphingomyelinase activation modulates TCR signaling by impairing storeoperated Ca2+ influx. J Leukoc Biol 78: 266-278, 2005.

12. Commerford SL, et al. Radiotoxicity of intranuclear ${ }^{125} \mathrm{I}$ atoms not bound to DNA. Int J Radiat Biol Relat Stud Phys Chem Med 37: 547-554, 1980.

13. Cordes $\mathrm{N}$, et al. Human pancreatic tumor cells are sensitized to ionizing radiation by knockdown of caveolin- 1 . Oncogene 26: 6851-6862, 2007.

14. Costantini DL, et al. ${ }^{111}$ In-labeled trastuzumab (herceptin) modified with nuclear localization sequences (NLS): an Auger electron-emitting radiotherapeutic agent for HER2/ neu-amplified breast cancer. J Nucl Med 48: 1357-1368, 2007.

15. Costantini DL, et al. Antitumor effects and normal-tissue toxicity of ${ }^{111}$ In-nuclear localization sequence-trastuzumab in athymic mice bearing HER-positive human breast cancer xenografts. J Nucl Med 51: 1084-1091, 2010.

16. Delpassand ES, et al. Safety and efficacy of radionuclide therapy with high-activity In-111 pentetreotide in patients 
with progressive neuroendocrine tumors. Cancer Biother Radiopharm 23: 292-300, 2008.

17. DeSombre ER, et al. Therapy of estrogen receptor-positive micrometastases in the peritoneal cavity with Auger electron-emitting estrogens-Theoretical and practical considerations. Acta Oncol 39: 659-666, 2000.

18. Galanis E, et al. Phase I trial of sequential administration of raltitrexed (Tomudex) and 5-iodo-2'-deoxyuridine (IdUrd). Ann Oncol 12: 701-707, 2001.

19. Hamada N. Evidence and significance of non-targeted effects of ionizing radiation. Curr Mol Pharmacol 4: 78, 2011.

20. Havaki S, et al. The role of oxidative DNA damage in radiation induced bystander effect. Cancer Lett 356: 43-51, 2015.

21. Hehlgans S, Eke I, and Cordes N. Targeting FAK radiosensitizes 3-dimensional grown human HNSCC cells through reduced Akt1 and MEK1/2 signaling. Int J Radiat Oncol Biol Phys 83: e669-e676, 2012.

22. Hofer KG and Hughes WL. Radiotoxicity of intranuclear tritium, 125 iodine and 131 iodine. Radiat Res 47: 94-101, 1971.

23. Humm JL, Howell RW, and Rao DV. Dosimetry of Augerelectron-emitting radionuclides: Report no. 3 of AAPM Nuclear Medicine Task Group No. 6. Med Phys 21: 19011915, 1994.

24. ICRP, A.o.t. (Ed). The 2007 Recommendations of the International Commission on Radiological Protection. Oxford: Elsevier, Vol. 37, 2007.

25. Kassis AI. Radiotargeting agents for cancer therapy. Expert Opin Drug Deliv 2: 981-991, 2005.

26. Kassis AI, et al. Lethality of Auger electrons from the decay of bromine-77 in the DNA of mammalian cells. Radiat Res 90: 362-373, 1982.

27. Kassis AI, et al. Radiotoxicity of an ${ }^{125} \mathrm{I}$-labeled DNA intercalator in mammalian cells. Radiat Res 118: 283-294, 1989.

28. Kassis AI, et al. Radiotoxicity of ${ }^{125} \mathrm{I}$ in mammalian cells. Radiat Res 111: 305-318, 1987.

29. Kassis AI, Sastry KS, and Adelstein SJ. Kinetics of uptake, retention, and radiotoxicity of ${ }^{125} \mathrm{IUdR}$ in mammalian cells: Implications of localized energy deposition by Auger processes. Radiat Res 109: 78-89, 1987.

30. Kohler G, Howe SC, and Milstein C. Fusion between immunoglobulin-secreting and nonsecreting myeloma cell lines. Eur J Immunol 6: 292-295, 1976.

31. Krenning EP, et al. The role of radioactive somatostatin and its analogues in the control of tumor growth. Recent Results Cancer Res 153: 1-13, 2000.

32. Lajoie $\mathrm{P}$, et al. Caveolin-1 regulation of dynamindependent, raft-mediated endocytosis of cholera toxin-B sub-unit occurs independently of caveolae. J Cell Mol Med 13: 3218-3225, 2009.

33. Lehnert BE, Goodwin EH, and Deshpande A. Extracellular factor(s) following exposure to alpha particles can cause sister chromatid exchanges in normal human cells. Cancer Res 57: 2164-2171, 1997.

34. Lev S, et al. Protein tyrosine kinase PYK2 involved in $\mathrm{Ca}(2+)$-induced regulation of ion channel and MAP kinase functions. Nature 376: 737-745, 1995.

35. Li L, et al. A Phase II study of anti-epidermal growth factor receptor radioimmunotherapy in the treatment of glioblastoma multiforme. J Neurosurg 113: 192-198, 2010.

36. Li PL and Gulbins E. Lipid rafts and redox signaling. Antioxid Redox Signal 9: 1411-1415, 2007.
37. Limouris GS, et al. Selective hepatic arterial infusion of In111-DTPA-Phe1-octreotide in neuroendocrine liver metastases. Eur J Nucl Med Mol Imaging 35: 1827-1837, 2008.

38. Lyng FM, et al. The involvement of calcium and MAP kinase signaling pathways in the production of radiationinduced bystander effects. Radiat Res 165: 400-409, 2006.

39. Lyng FM, Seymour CB, and Mothersill C. Initiation of apoptosis in cells exposed to medium from the progeny of irradiated cells: A possible mechanism for bystanderinduced genomic instability? Radiat Res 157: 365-370, 2002.

40. Macapinlac HA, et al. Pilot clinical trial of 5-[ $\left.{ }^{125} \mathrm{I}\right]$ iodo- $2^{\prime}-$ deoxyuridine in the treatment of colorectal cancer metastatic to the liver. J Nucl Med 37: 25S-29S, 1996.

41. Mariani G, et al. Tumor targeting in vivo and metabolic fate of 5-[iodine-125]iodo-2'-deoxyuridine following intratumoral injection in patients with colorectal cancer. J Nucl Med 34: 1175-1183, 1993.

42. Mothersill C and Seymour CB. Cell-cell contact during gamma irradiation is not required to induce a bystander effect in normal human keratinocytes: Evidence for release during irradiation of a signal controlling survival into the medium. Radiat Res 149: 256-262, 1998.

43. Nagasawa $\mathrm{H}$, et al. Involvement of membrane signaling in the bystander effect in irradiated cells. Cancer Res 62: 2531-2534, 2002.

44. Narayanan PK, Goodwin EH, and Lehnert BE. Alpha particles initiate biological production of superoxide anions and hydrogen peroxide in human cells. Cancer Res 57: 3963-3971, 1997.

45. Oskouian B and Saba JD. Cancer treatment strategies targeting sphingolipid metabolism. Adv Exp Med Biol 688: 185-205, 2010.

46. Paillas S, et al. Apoptosis and p53 are not involved in the anti-tumor efficacy of ${ }^{125}$ I-labeled monoclonal antibodies targeting the cell membrane. Nucl Med Biol 40: 471-480, 2013.

47. Patel HH, Murray F, and Insel PA. Caveolae as organizers of pharmacologically relevant signal transduction molecules. Aпnи Rev Pharmacol Toxicol 48: 359-391, 2008.

48. Piron B, et al. DNA damage-centered signaling pathways are effectively activated during low dose-rate Auger radioimmunotherapy. Nucl Med Biol 41 Suppl: e75-e83, 2014.

49. Pomplun E, Booz J, and Charlton DE. A Monte Carlo simulation of Auger cascades. Radiat Res 111: 533-552, 1987.

50. Pouget JP, et al. Cell membrane is a more sensitive target than cytoplasm to dense ionization produced by auger electrons. Radiat Res 170: 192-200, 2008.

51. Prise KM and O'Sullivan JM. Radiation-induced bystander signalling in cancer therapy. Nat Rev Cancer 9: 351-360, 2009.

52. Quang TS and Brady LW. Radioimmunotherapy as a novel treatment regimen: ${ }^{125}$ I-labeled monoclonal antibody 425 in the treatment of high-grade brain gliomas. Int $J$ Radiat Oncol Biol Phys 58: 972-975, 2004.

53. Santoro L, et al. Noninternalizing monoclonal antibodies are suitable candidates for ${ }^{125} \mathrm{I}$ radioimmunotherapy of small-volume peritoneal carcinomatosis. J Nucl Med 50: 2033-2041, 2009.

54. Sastry KS and Rao DV. Dosimetry of low energy electrons. In: Physics of Nuclear Medicine: Recent Advances, edited 
by Rao DV, Chandra R, and Graham MC. New York: American Institute of Physics, 1984, pp. 169-208.

55. Sawant SG, et al. The bystander effect in radiation oncogenesis: I. Transformation in $\mathrm{C} 3 \mathrm{H} 10 \mathrm{~T} 1 / 2$ cells in vitro can be initiated in the unirradiated neighbors of irradiated cells. Radiat Res 155: 397-401, 2001.

56. Scheel-Toellner D, et al. Reactive oxygen species limit neutrophil life span by activating death receptor signaling. Blood 104: 2557-2564, 2004.

57. Singer SJ, and Nicolson GL. The fluid mosaic model of the structure of cell membranes. Science 175: 720-731, 1972.

58. Sisson JC, et al. Treatment of neuroblastoma with $\left[{ }^{125}\right.$ I] metaiodobenzylguanidine. J Nucl Biol Med 35: 255259, 1991.

59. Smith EL and Schuchman EH. The unexpected role of acid sphingomyelinase in cell death and the pathophysiology of common diseases. FASEB J 22: 3419-3431, 2008.

60. Todd DG, et al. Ionizing radiation stimulates existing signal transduction pathways involving the activation of epidermal growth factor receptor and ERBB-3, and changes of intracellular calcium in A431 human squamous carcinoma cells. J Recept Signal Transduct Res 19: 885908, 1999.

61. Valerie $\mathrm{K}$, et al. Radiation-induced cell signaling: insideout and outside-in. Mol Cancer Ther 6: 789-801, 2007.

62. Vallis KA, et al. Phase I trial to evaluate the tumor and normal tissue uptake, radiation dosimetry and safety of (111)In-DTPA-human epidermal growth factor in patients with metastatic EGFR-positive breast cancer. Am J Nucl Med Mol Imaging 4: 181-192, 2014.

63. Walicka MA, Adelstein SJ, and Kassis AI. Indirect mechanisms contribute to biological effects produced by decay of DNA-incorporated iodine-125 in mammalian cells in vitro: clonogenic survival. Radiat Res 149: 142-146, 1998.

64. Walicka MA, Adelstein SJ, and Kassis AI. Indirect mechanisms contribute to biological effects produced by decay of DNA-incorporated iodine-125 in mammalian cells in vitro: double-strand breaks. Radiat Res 149: 134-141, 1998.

65. Welt S, et al. Phase I/II study of iodine 125-labeled monoclonal antibody A33 in patients with advanced colon cancer. J Clin Oncol 14: 1787-1797, 1996.

66. Xue LY, et al. Bystander effect produced by radiolabeled tumor cells in vivo. Proc Natl Acad Sci U S A 99: 1376513770, 2002.

67. Zhang AY, et al. Acid sphingomyelinase and its redox amplification in formation of lipid raft redox signaling platforms in endothelial cells. Antioxid Redox Signal 9: 817-828, 2007.

68. Zhang Y, et al. Ceramide-enriched membrane domainsStructure and function. Biochim Biophys Acta 1788: 178183, 2009.
Address correspondence to: Dr. Jean-Pierre Pouget

Institut de Recherche en Cancérologie (IRCM)

INSERM U1194

208 rue des apothicaires 34298 Montpellier cedex 5

France

E-mail: jean-pierre.pouget@inserm.fr

Date of first submission to ARS Central, November 26, 2015; date of final revised submission, May 17, 2016; date of acceptance, May 23, 2016.

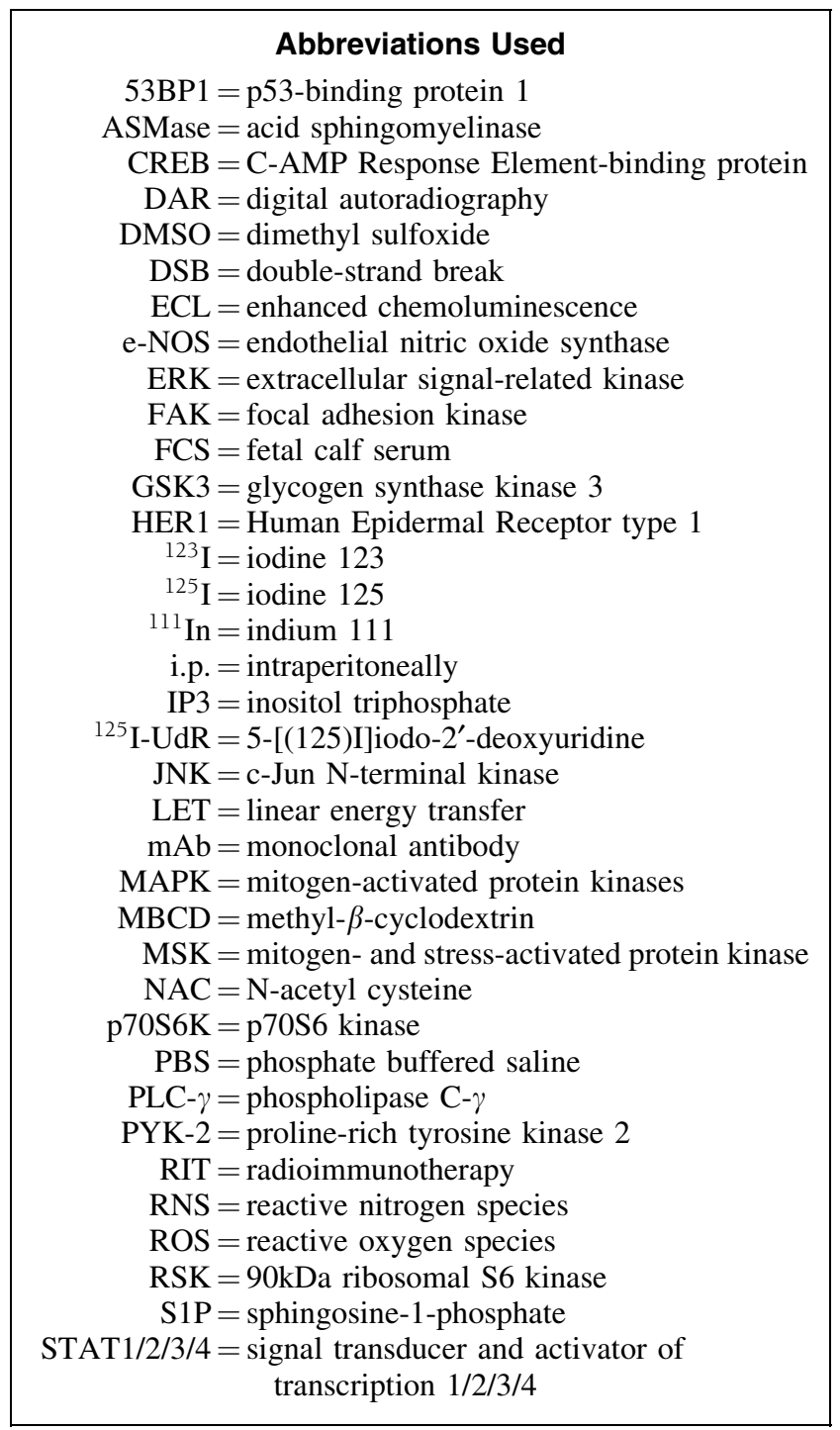

